Niğde Ömer Halisdemir Üniversitesi Mühendislik Bilimleri Dergisi
Niğde Ömer Halisdemir University Journal of Engineering Sciences
ISSN: 2564-6605
Araştırma / Research

\title{
Betonarme kolonların dayanım zarflarının kesme dayanımı modelleri ile karşılaştırılması
}

\section{Comparison of strength envelopes of $\mathrm{RC}$ columns with shear strength models}

\author{
Tamer Dirikgil ${ }^{1}$ \\ ${ }^{1}$ Erciyes Üniversitesi, Mühendislik Fakültesi, Inşaat Mühendisliği Bölümü, 38039, Kayseri, Türkiye
}

\section{Özet}

Bu çalışmada sabit eksenel yük ve çevrimsel yatay yük etkisi altında test edilen oniki adet betonarme kolonun deneysel dayanımlart ile yaygın olarak kabul gören yedi kesme dayanımı modelinden elde edilen kesme kapasiteleri değerlendirilmiştir. Bu değerlendirmede kolonların kesme açıklı̆̆ oranları, etriye çapları, beton dayanımları ve eksenel yük indeksleri birer parametre olarak dikkate alınmıștır. Değerlendirmeye alınan kesme dayanımı modellerinden üçü yönetmelik modelleridir. Diğer dört model ise artan düktilite talebine bağll olarak çevrimsel yükleme ile kesme dayanımı azalmasını dikkate alan kesme dayanımı zarfi modelleridir. Değerlendirme neticesinde kesme dayanımı zarflart hem dayanımın belirlenmesinde hem de kesme dayanımı azalmasının benzeşiminde oldukça başarll olmuştur. Yönetmelik modellerinin tasarıma yönelik olarak ihtiyatlı sonuçlar verdiği, ancak çevrimsel yükleme ile dayanım azalmasının dikkate alınması gerektiği görülmüşı̈̈r. Kesme açıklı̆̆ oranı 1.5 olan kolonlar kesme hakim davranış için kritiktir ve yönetmeliklerde bu durum dikkate alınmalıdır. Eksenel yük indeksinin çevrimsel yük etkisi altında davranışa etkisi tüm modeller tarafindan ayrica ele alınmalıdır.

Anahtar kelimeler: Betonarme kolon, Çevrimsel yük, Kesme dayanımı, Dayanım azalması modelleri

\section{Giriş}

Betonarme (BA) elemanların kesme kırılmaları genellikle düşük deformasyon seviyelerinde gerçekleşir ve yük tepkisi ani bir şekilde azalma eğilimi gösterir. Bu nedenle, modern yönetmeliklerin öngördüğü tasarımlarda daha büyük deformasyon kabiliyeti ve düktil davranışla eğilmeden kaynaklı akmanın kesme kırılmasından önce gerçekleşmesi sağlanarak kesme kırılmasının önüne geçilmesi hedeflenir. Şu noktada kesme kırılması riskinin modern yönetmeliklere göre detaylandırılmamış elemanlar için daha tehlikeli olduğu söylenebilse de, FEMA274 [1]'de modern yönetmeliklere göre tasarlanmış elemanlarda da kesme kırılmalarının meydana geldiği rapor edilmiştir. BA elemanların kesme dayanımları çevrimsel yük etkisi altında eğilme dayanımından daha hızlı bir şekilde düşer [2]. Bu nedenle BA yapısal elemanlar için tekdüze yükleme değerinin altında kalan ve çevrimsel yüklemeye bağlı olarak gelişen kesme dayanımı azalması dikkate alınmalıdır.

Dünya çapındaki birçok standart, yönerge veya yönetmelikte çok sayıda kesme dayanımı modelleri ve tasarım formülasyonları bulunmaktadır. Genel olarak tasarım amaçlı kullanılan standart/yönetmelik formülasyonları yaklaşık bir asır önce Ritter ve Mörsch [3, 4] tarafından önerilen kafes analojisi modeline dayanır. Kafes analojisi modeli, eleman doğrultusuyla $45^{\circ}$ açı yapan
Abstract

The experimental strengths of twelve reinforced concrete columns, tested under the effect of constant axial load and cyclic lateral load, and the shear capacities obtained from seven widely accepted shear strength models were evaluated in this study. The shear spans, stirrup diameters, concrete strength, and axial load indexes of the columns were considered as parameters. Three of the shear strength models evaluated were regulation/code models. The other five models were shear strength envelope models that consider the shear strength degradation depending on cyclic loading and increasing ductility demand. The evaluation result showed that models of shear strength envelope are quite successful in both determining strength and simulating shear strength degradation. Regulation models take a conservative approach to design, but it has been observed that strength degradation with cyclic loading should be considered. Columns with a shear span of 1.5 are critical to sheardominant behavior and regulations should take this into account. A further consideration is required for all models in assessing the effect of axial load index on behavior under cyclic loading.

Keywords: RC columns, Cyclic load, Shear strength, Strength degradation models

beton basınç çubukları ile kesme donatılarını ve boyuna donatıları temsil eden çekme çubuklarının oluşturduğu kafes örgüsü modeline dayanmaktadır. Kafes analojisi, mevcut elemanların kesme dayanımlarının hesaplanmasında kafes çubuk eğimi ve (eğilme-kesme etkileşimi, aderans kaybı, lineer olmayan davranış gibi durumların dikkate alınması için) beton basınç dayanımı üzerindeki ciddi kısıtlamalar nedeniyle çoğunlukla ihtiyatlı şekilde düşük sonuçlar vermektedir $[5,6]$. Bu noktada salt kesme etkisinin dikkate alındığı vurgulanmalıdır.

Tasarım formülasyonlarının yanı sıra, klasik teorik yaklaşımların eksikliklerinin giderilmesi için başka teorik öneriler de söz konusu olmuştur. Bunlardan biri bilgisayar yazılımlarının da doğrusal olmayan sonlu elemanlar analizi yapılmasında esas aldığı Değiştirilmiş Basınç Alanı Teorisi [7] (MCFT-Modified Compression Field Theory)'dir. MCFT kesmeye maruz kalan iki boyutlu çatlamış betonarmenin yük-deformasyon davranışını tanımlayan genel bir modeldir. MCFT modeldeki en önemli varsayım, betonarmede çatlamış betonun amprik olarak tanımlanan gerilme-şekil değiştirme yaklaşımı ile yeni bir malzeme olarak değerlendirilmesidir. $\mathrm{Bu}$ model Bentz vd. [8] tarafindan 100 adet salt kesme etkisi altındaki eleman üzerinde yapılan deneysel çalışmalarla önemli ölçüde basitleştirilmiştir. Basitleştirilen bu model SMCFT

\footnotetext{
* Sorumlu yazar / Corresponding author, e-posta / e-mail: dirikgil@erciyes.edu.tr Geliş / Recieved: 08.12.2020 Kabul / Accepted: 18.12.2020 Yayımlanma / Published: 15.01.2021 doi: $10.28948 /$ ngmuh. 837836
} 
(Simplified Modified Compression Theory) olarak tanıtılmış ve bazı standart ya da yönergelerde $[9,10]$ yer almıştır.

Son yıllarda, BA elemanların kesme dayanımlarının belirlenmesindeki doğruluğu artırmak için bazı kapasite modelleri ve basitleştirilmiş formülasyonlar önerilmiştir. Özellikle, deneysel çalışma verilerinin ve test parametrelerinin artması, bu basitleştirilmiş modellerin genel uygulamalarda kullanılabilmesi için kalibre edilmelerine ve değerlendirilmelerine olanak sağlamıştır. Bu modeller deneysel verilerin ortalama değerleri dikkate alınarak kalibre edilmiştir. Bu modellerde çevrimsel yük etkisi altında kesmeyi kritik hale getiren dayanım azalması sünekliğin bir fonksiyonu olarak dikkate alınmaktadır. Bu doğrultuda yapılan çalışmalarda, deneysel bulguların özellikle yönetmeliklere uygun olmayan BA elemanlarda çevrimsel yükleme ile sünekliğin azaldığını, kesme kırılmalarının erken gerçekleştiğini [11-13], dolayısıyla bu durumun elemanın yatay tepkisini önemli ölçüde etkilediğini [14] gösterdiği belirtilmiştir. Süneklik talebindeki artışla kesme dayanımındaki azalma, sünek eğilme kırılması davranışını eğilme akmasından sonra ani dayanım kaybı ile tehlikeli kesme kırılmasına yönlendirebilir [15]. Kesmenin hakim olduğu bu kesmeli eğilme davranışı, sünekliğin 1 olduğu noktadan sonra dayanımdaki azalmayı tarifleyen modern kapasite modelleri ile hesaba katılmaktadır. Bu modellerin bazıları bazı modern yönetmelik ve/veya yönergeler tarafindan benimsenmiştir.

Kesme dayanımının sünekliğin bir fonksiyonu olarak azalmasını tarifleyen ilk çalışmalardan biri Priestley vd. [16] tarafından öne sürülmüştür. UCSD (University of California at San Diego) modeli olarak bilinen bu modelde, BA kolonlar için betonun, kesme donatısının ve eksenel yükün kesmeye katkısının dikkate alındığı bir dayanım zarfı modeli önerilmiştir. Bunun ardından, kesme açıklığı oranını ve boyuna donatı oranının beton kesme kapasitesi üzerindeki etkisini dikkate almayan orijinal UCSD modelinin bu eksikliğini gidermek için Kowalsky ve Priestley tarafından revize edilmiş UCSD modeli sunulmuştur [17]. Bu model dairesel kolonlar ve perde duvarlar için oluşturulmuş olsa da, genellikle yaygın uygulamada dikdörtgen kolonlar için kullanılmaktadır [2].

ATC sismik tasarım yönergesi [18] yer değiştirme düktilitesi ile kesme dayanımının azalmasını dikkate alan bir kesme kapasitesi eğrisi önermiştir (Şekil 1).

Sezen ve Moehle [19] tarafindan; kolonların kesme açıklığı oranının, eksenel yükün ve kesme donatısı oranının yer değiştirme düktilitesine bağlı olarak kesme dayanımına katkısını dikkate alan bir başka model önerilmiştir. Biskinis vd [2] tarafindan iki model önerisi sunulmuştur. Bunlardan ilki; eksenel yükün kesme dayanımı üzerindeki etkisini diyagonal basınç çubuğu (strut) mekanizması ve kesme donatılarının kesme dayanımına katkısını klasik kafes analojisini esas alarak tanımlayan bir modeldir. İkinci model ise diyagonal basıncın $45^{\circ}$ 'den farklı bir açıda kolonun köşegeni boyunca olduğunu varsayar. Biskinis ve Fardis [20] elemanın kırılma modunu dikkate alarak, ilk modeli"stirrupyielding" (etriye akması), ikinci modeli ise "web-crushing" (gövde ezilmesi) olarak tanımlamışlardır. Bu modellerden her biri betonun, kesme ve boyuna donatı oranlarının
(Biskinis-web crushing kesme donatısı oranını dikkate almaz), kesme açıklığı oranının, en kesit boyutlarının ve eksenel yükün kesit dayanımına katkısını dikkate alan kesme dayanımı zarfları önermektedir.

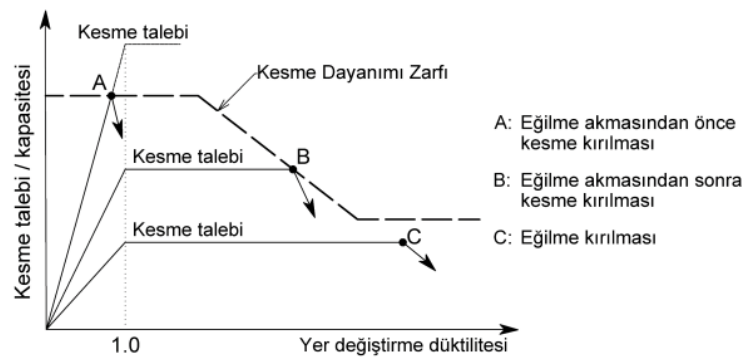

Şekil 1. ATC kesme dayanımı zarfı modeli [18]

$\mathrm{Bu}$ çalışmada çevrimsel yükleme altında testi gerçekleştirilmiş olan on iki adet BA kolonun kesme dayanımları, yukarıda belirtilen açıklamalar doğrultusunda seçilen yedi ayrı kesme dayanımı modeli kullanılarak tahmin edilmiş ve elde edilen bulgular deneysel verilerle kıyaslanmıştır. Testi gerçekleştirilen kolonlar modern yönetmeliklerin [21-23] tasarım koşullarına uygun olarak üretilmiş boyut ve donatı detayı bakımında kusurlu olmayan kolonlardır. Test kolonları; kesme açıklığı oranı, etriye çap1, beton dayanımı ve eksenel yük indeksi farklı olan kolonlardan seçilerek en kesit boyutlarına göre gruplandırılmıştır. Çalışma kapsamında kesme açıklığı oranı, etriye çapı, beton dayanımı ve eksenel yük indeksinin parametre olarak belirlendiği deneysel veriler kullanılarak kesme dayanımı modellerinin tahmin öngörülerinin değerlendirilmesi amaçlanmıştır.

\section{Materyal ve metot}

$\mathrm{Bu}$ çalışmada sabit eksenel yük ve tersinir tekrarlanır yatay yük etkisi altında test edilen on iki adet BA kolonun dayanım zarfları ile kesme dayanımı modellerinin tahminlerinin karşılaştırması yapılmıştır. Bu karşılaştırmanın farklı parametreler dikkate alınarak yapılabilmesi için, test kolonları yazarın kolonların güçlendirilmesine yönelik yaptığı bir Tübitak projesi kapsamında yer alan güçlendirilmemiş kolonlar arasından seçilmiştir. Seçilen kolonlarla birlikte bu çalışma kapsamında yedi mevcut kesme dayanımı formülasyonu değerlendirmeye alınmıştır. Bunlardan ikisi kafes analojisini esas alan yönetmelik modelleri [21, 24], biri değiştirilmiş basınç alanı teorisinin basitleştirilmiş versiyonunu (SMCFTsimplified modified compression field theory) esas alan model [9] ve dördü ise düktiliteye bağlı olarak kesme dayanımı azalmasını esas alan modeller [2, 17, 19] olarak belirlenmiştir. Kolonların deneysel olarak belirlenmiş dayanım zarfları ile kesme dayanımı modellerinden elde edilen kapasite sonuçları kıyaslanarak ortaya konulmuştur.

\subsection{Test kolonlar}

$\mathrm{Bu}$ çalışmada yer alan test kolonları iki gruba ayrılmıştır. Birinci grup aynı enkesit boyutlarına sahip ve ortak üretimle imal edilen ancak kesme açıklığı oranları ve etriye çapları farklı olan kolonlardan oluşmaktadır. İkinci grup ise en kesit boyutları ve kesme açıklığı oranları aynı ancak beton 
dayanımları ve eksenel yük indeksleri (n) farklı olan kolonlardır. Dolayısıyla bu çalışma kapsamında kesme dayanımı zarfi modellerinin tahminlerinin değerlendirilmesinde; birinci grup için kesme açıklığ oranının ve etriye çapının bir parametre olarak dikkate alınması, ikinci grup için ise beton dayanımı ve eksenel yük indeksi parametrelerinin değerlendirilmesi mümkün olmaktadır. Tüm kolonlar $8 \varnothing 16$ boyuna donatıya sahiptir.

Birinci grup (Grup-1) kolonlarının en kesit boyutları $400 \times 400 \mathrm{~mm}^{2}$ olup, kolonlara yatay yük $800 \mathrm{~mm}, 600 \mathrm{~mm}$ ve $400 \mathrm{~mm}$ seviyelerinden uygulanmıştır. Dolayısıyla Grup-1 kolonlarının kesme açıklığı oranları $\left(\alpha_{s}\right)$ sırasıyla $2,1.5$ ve 1 'dir. Kesme açıklığg oranı 2.5'den az olan kolonlarda kesme deformasyonunun etkisi yatay yük ile birlikte artmaktadır $[25,26]$. Şu durumda dikkate alınan kesme açıklığ oranlarına bağlı olarak davranışta eğilmenin yanı sıra kesme etkileşiminin ve buna bağlı hasarların da göz önüne alınması amaçlanmıştır. Kesme oranı $\alpha_{s}=M / V h$ ile tariflenmekte olup, tek eğrilikli kolonlar için $\alpha_{s}=M / V h=L_{s} / h$ 'dır. Şu durumda birinci grup kesme açıklığ 1 oranı $\alpha_{s}=2-1.5-1$ olarak değişen üç seriden oluşmaktadır. Her seride etriye çapı $\varnothing 10$ ve $\emptyset 12$ olan iki kolon yer almaktadır. Dolayısıyla birinci grupta 3 (seri) $\times 2$ (etriye çap1) olmak üzere toplam altı adet kolon yer almaktadır. Grup-1 kolonlarının tamamı etriye aralığ $100 \mathrm{~mm}$ olan ve güncel yönetmelik şartlarını [21-23] sağlayan kusursuz kolonlardır. Grup-1 kolonlarının en kesit ve boykesit detayları Şekil 2.(a)'da görsel olarak verilmiştir. Tablo 1'de ise kolonlara ait değişkenler sayısal olarak görülebilir.

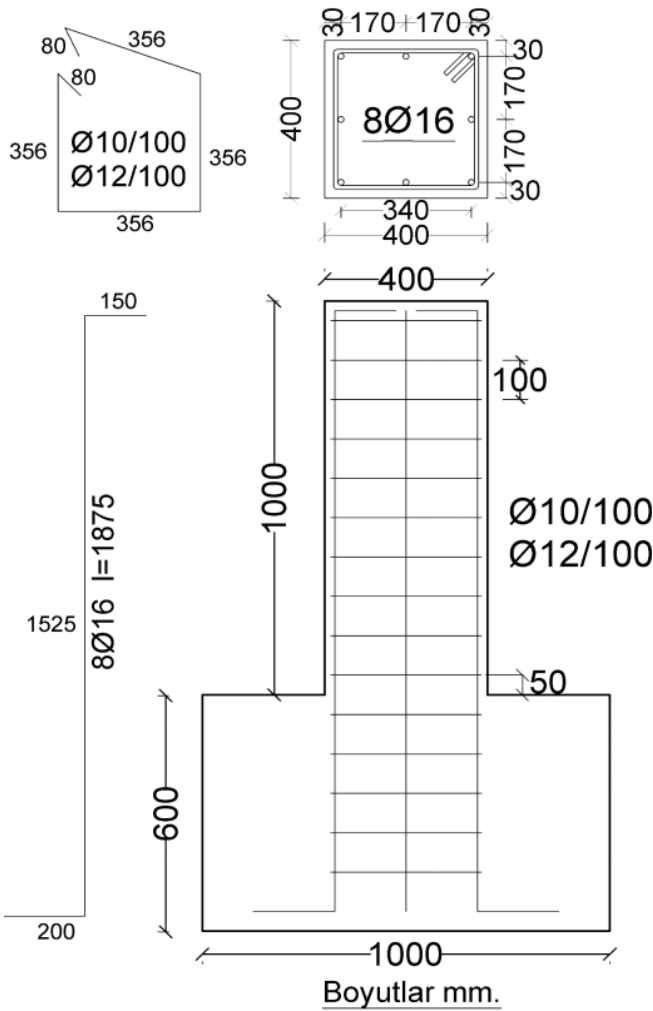

(a)
İkinci grup (Grup-2) kolonlarının en kesit boyutları $300 \times 300 \mathrm{~mm}^{2}$ 'dir. Kolonlara yatay yük $450 \mathrm{~mm}$ seviyesinden uygulanmıştır. Dolayısıyla Grup-2 kolonlarının tamamı için kesme açıklığ 1 oranı aynı olup $\alpha_{s}=1.5$ 'tir. Grup-2 kolonları beton dayanımı (BD) ve eksenel yük indeksi (n) değişimine göre iki seriye ayrılmıştır. İkinci grubun beton dayanımı serisinde beton dayanımı sırasıyla yaklaşık $\mathrm{BD}=30-40$ $50 \mathrm{MPa}$ olan üç kolon, eksenel yük indeksi serisinde ise $\mathrm{n}=0.3-0.4-0.5$ olan üç kolon yer almaktadır. İkinci grupta 2 $($ seri $) \times 3$ (BD veya $n)$ olmak üzere toplam altı adet kolon yer almaktadır. İkinci grup kolonlarının tamamında $\varnothing 10 / 100$ etriye kullanılmış olup, bu kolonlar da güncel yönetmelik şartlarını [21-23] sağlayan kusursuz kolonlardır. BD serisinde eksenel yük indeksi $n=0.2$ olarak sabit iken, $n$ serisinde ise ortalama beton dayanımı 22.13MPa'dır. Grup2 kolonlarının en kesit ve boykesit detayları Şekil 2.(b)'de görsel olarak verilmiştir. Tablo 1 'de ise kolonlara ait değişkenler sayısal olarak görülebilir.

Kolonlar $\quad \mathrm{BK}_{\mathrm{G}}-\alpha_{s}-B D-n-\varnothing_{w} \quad$ şeklinde notasyonlandırılmıştır. Çalışmanın devamında bu notasyonlar içerisinde gruplara ait değişkenler parantez içinde verilerek vurgulanacaktır. Burada:

BK: Betonarme Kolon

G: Grup

$B D$ : beton dayanımını temsilen beton sınıf

$\alpha_{s}:$ kesme açıklığı oranı

$\mathrm{n}$ : eksenel yük indeksi

$\emptyset_{\mathrm{w}}$ : etriye çapıdır.

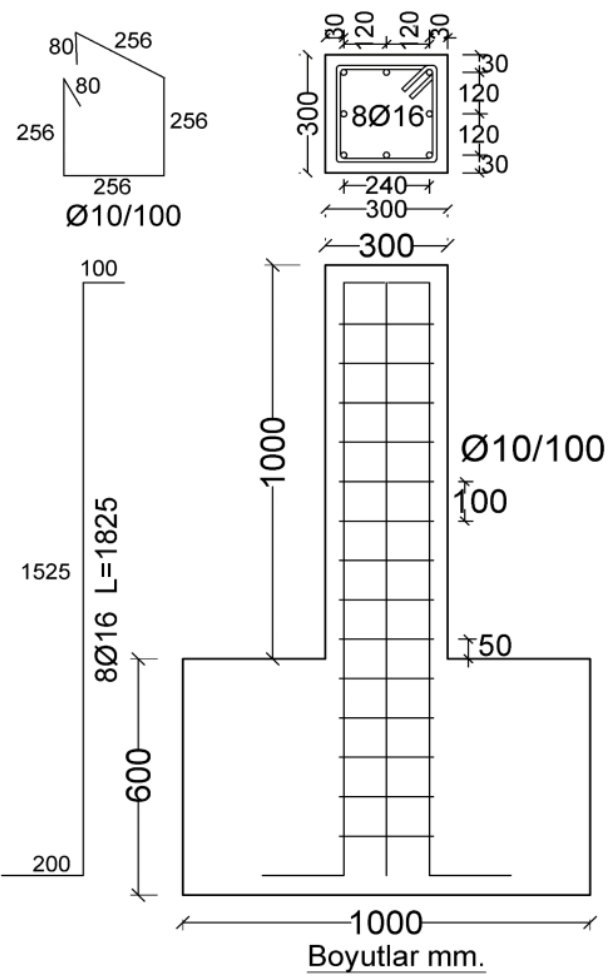

(b)

Şekil 2. (a) Grup 1 (b) Grup 2 kolonlarının en kesit ve boy kesit detayları

Tablo 1. Kolonların boyut ve parametreleri 


\begin{tabular}{lccccccc}
\hline \multicolumn{1}{c}{ Kolon } & $\begin{array}{c}b \times h \\
\mathrm{~mm}^{2}\end{array}$ & $\alpha_{s}$ & $\begin{array}{c}f_{c} \\
\mathrm{MPa}\end{array}$ & $n$ & $\rho_{l}$ & $\rho_{w}$ & $\begin{array}{c}f_{y} \\
\mathrm{MPa}\end{array}$ \\
\hline $\mathrm{BK}_{1}-(2)-\mathrm{C} 25-0.2-(\varnothing 10)$ & $400 \times 400$ & 2 & 28.07 & 0.2 & 0.010053 & 0.003927 & 448.13 \\
$\mathrm{BK}_{1}-(2)-\mathrm{C} 25-0.2-(\varnothing 12)$ & $400 \times 400$ & 2 & 28.07 & 0.2 & 0.010053 & 0.005655 & 448.13 \\
$\mathrm{BK}_{1}-(1.5)-\mathrm{C} 25-0.2-(\varnothing 10)$ & $400 \times 400$ & 1.5 & 28.07 & 0.2 & 0.010053 & 0.003927 & 448.13 \\
$\mathrm{BK}_{1}-(1.5)-\mathrm{C} 25-0.2-(\varnothing 12)$ & $400 \times 400$ & 1.5 & 28.07 & 0.2 & 0.010053 & 0.005655 & 448.13 \\
$\mathrm{BK}_{1}-(1)-\mathrm{C} 25-0.2-(\varnothing 10)$ & $400 \times 400$ & 1 & 28.07 & 0.2 & 0.010053 & 0.003927 & 448.13 \\
$\mathrm{BK}_{1}-(1)-\mathrm{C} 25-0.2-(\varnothing 12)$ & $400 \times 400$ & 1 & 28.07 & 0.2 & 0.010053 & 0.005655 & 448.13 \\
\hline $\mathrm{BK}_{2}-1.5-(\mathrm{C} 30)-0.2-\varnothing 10$ & $300 \times 300$ & 1.5 & 32.24 & 0.2 & 0.017872 & 0.005236 & 453.28 \\
$\mathrm{BK}_{2}-1.5-(\mathrm{C} 40)-0.2-\varnothing 10$ & $300 \times 300$ & 1.5 & 39.27 & 0.2 & 0.017872 & 0.005236 & 453.28 \\
$\mathrm{BK}_{2}-1.5-(\mathrm{C} 50)-0.2-\varnothing 10$ & $300 \times 300$ & 1.5 & 51.73 & 0.2 & 0.017872 & 0.005236 & 453.28 \\
$\mathrm{BK}_{2}-1.5-\mathrm{C} 20-(0.3)-\varnothing 10$ & $300 \times 300$ & 1.5 & 22.13 & 0.3 & 0.017872 & 0.005236 & 453.28 \\
$\mathrm{BK}_{2}-1.5-\mathrm{C} 20-(0.4)-\varnothing 10$ & $300 \times 300$ & 1.5 & 22.13 & 0.4 & 0.017872 & 0.005236 & 453.28 \\
$\mathrm{BK}_{2}-1.5-\mathrm{C} 20-(0.5)-\varnothing 10$ & $300 \times 300$ & 1.5 & 22.13 & 0.5 & 0.017872 & 0.005236 & 453.28 \\
\hline
\end{tabular}

\subsection{Deney düzeneğ $i$}

Deney düzeneği iki yatay yükleme ünitesi ve bir düşey yükleme ünitesinden oluşmaktadır. $\mathrm{Bu}$ ünitelerde yük hücreleri, mafsallar ve diğer bağlantı elemanları yer almaktadır. Test kolonları tam ölçekli olduğundan, özellikle $\alpha_{\mathrm{s}}=1$ kesme oranına sahip kolonlarda, oldukça büyük yatay yük seviyelerine ulaşılmaktadır. Büyük yatay yük seviyelerinde tek noktadan çevrimsel yükleme yapılması bağlantı elemanlarının aşırı zorlanmasına neden olmakta ve iş sağlı̆̆ını tehlikeye atmaktadır. $\mathrm{Bu}$ nedenle kolonlara karşılıklı yatay yük uygulanarak çevrimsel yükleme yapılmıştır [27]. Krikolardan biri yükleme yaparken diğerinin yağ basıncı serbest bırakıldığında karşı bir tepki oluşmamaktadır [28]. Deney düzeneğinin bir görünümü Şekil 3'de verilmektedir.

\subsection{Yükleme prosedürü}

Yatay yükleme prosedürü FEMA461'de [29] belirtilen yapısal bileşenlerin yer değiştirme kontrollü olarak yüklenmesine ilişkin statik yük uygulaması takip edilerek uygulanmıştır. Kolonların gevrek davranış karakterleri nedeniyle, küçük yer değiștirme değerlerinde büyük hasarlar meydana gelmesi olası olduğundan, küçük yer değiştirme artışları ile deneye devam edilmesi daha uygun olmaktadır. Böylece hem davranış daha net gözlemlenmekte, hem de birkaç döngü sonra meydana gelecek ani göçmelerden sakınılmış olmaktadır. Yüklemenin sıfır-itme-çekme-sıfır yolunu izlemesi bir döngüdür. Her döngü prosedür gereği 2 kez tekrarlanmaktadır. Dolayısıyla peş peşe tekrarlanan 2 döngü 1 adımı oluşturmaktadır. Prosedür gereği en az 10 adım çevrimsel yükleme uygulanması gerektiğinden, yük adımları hedef yer değiştirmelere 10.adımda ulaşılacak şekilde belirlenmiştir. Hedef yer değiştirme kolonun etkili boyuna göre $\% 3$ göreli ötelenme olarak dikkate alınmıștır. Prosedür gereği, yük adımları 10.adıma kadar her adımda 1.4 kat, kolonun kırılmaması durumunda 10.adımdan sonra $1.3 \mathrm{~kat}$ artırılarak uygulanmıştır. Yatay yükleme prosedürü yer değiştirme-adım grafiği Şekil 4'de verilmektedir.

Kolonlara çevrimsel yüklemelerden önce eksenel yük indeksine (n) bağlı olarak eksenel yük uygulanmış ve eksenel yük seviyesi deneyler boyunca sabit tutulmuştur. Grup-1 kolonlarına ve Grup-2 BD serisi kolonlara $n=0.2$, Grup-2 $\mathrm{n}$ serisi kolonlara ise $\mathrm{n}=0.3-0.4-0.5$ indeksleri ile eksenel yük $\left(\mathrm{N}=\mathrm{nA}_{\mathrm{c}} \mathrm{f}_{\mathrm{c}}\right)$ uygulanmıştır.

\subsection{Kesme dayanımı modelleri}

$\mathrm{Bu}$ çalışma kapsamında, deneysel olarak belirlenen BA kolon yatay yük dayanımlarının, yönetmelik ve diğer dayanım modellerinin amprik ifadelerinden elde edilen kapasite sonuçlarıyla kıyaslanması için yaygın kullanıma sahip yedi kesme dayanımı modeli dikkate alınmıştır. Yönetmelik modelleri tasarıma yönelik olarak mevcut dayanımı belirlemek yerine kesme kırılmasından uzak kalma amacıyla ihtiyatlı bir yaklaşım benimserken, kesme dayanımı zarfi (KDZ) modelleri olarak adlandırılan dayanım azalması modelleri çevrimsel yükleme ve artan düktilite talebine bağlı olarak oluşturulan zarflarla davranışı yakalamayı amaçlamaktadır. Şu noktada yönetmelik modellerinden mevcut dayanımı belirlemesi değil, hesaplanan dayanım aşıldıktan sonra hangi seviyede kesme kırılmasının meydana geldiğini sorgulamak gerekir. Yönetmelikler belirli bir güven aralığı da dikkate aldıklarından, mevcut dayanım hesaplanan değerin biraz üstünde olsa dahi kesme kırılması beklenmeyebilir. $\mathrm{Bu}$ çalışmada yönetmeliklerin ihtiyatlı yaklaşım için belirlediği güven aralığının çevrimsel yüklemeye maruz kalan kolonlar için değerlendirilmesi yapılırken, KDZ modellerinin ise mevcut dayanımın belirlenmesinde ve mevcut davranışın benzeşiminde uyumlulukları incelenmiştir. Çalışma kapsamında dikkate alınan kesme dayanımı modelleri bu kısımda genel hatlarıyla açıklanmış, amprik ifadeleri ise Ek A'da verilmiştir. Çalışma içerisindeki tablolarda ve amprik ifadelerde yer alan kısaltmaların açıklamaları Ek B'de kısaltmalar listesi olarak verilmiştir.

\subsubsection{Kafes analojisi modelleri}

Kafes analojisi modelleri, genellikle yeni yapıların sismik tasarımı için yönetmelikler tarafından önerilir ve genellikle değerlendirme amacıyla kullanılır. Ayrıca, kafes modelleri, mevcut elemanlar için FRP tabanlı kesme güçlendirmesi çözümlerinin tasarımında da inşa edilmiş eleman kapasitesini tahmin etmek için sıklıkla kullanılır [30-32]. Mevcut tasarım yönetmeliklerinde döngüsel yükleme altında kesme dayanımındaki azalma iyi bilinmektedir. Bununla birlikte, dayanım azalması elemanın deformasyon seviyesi açısından açık bir şekilde tanımlanmaz ve ihtiyatlı bir hesaplama yoluna gidilir [33]. Bu çalışma kapsamında ACI318-19 [21] ve TS500/2000 [24] kodlarında kesit kesme kapasitesinin hesaplaması için verilen amprik ifadeler dikkate alınmıştır. Bu tasarım kodlarında yer alan kesme 
3206
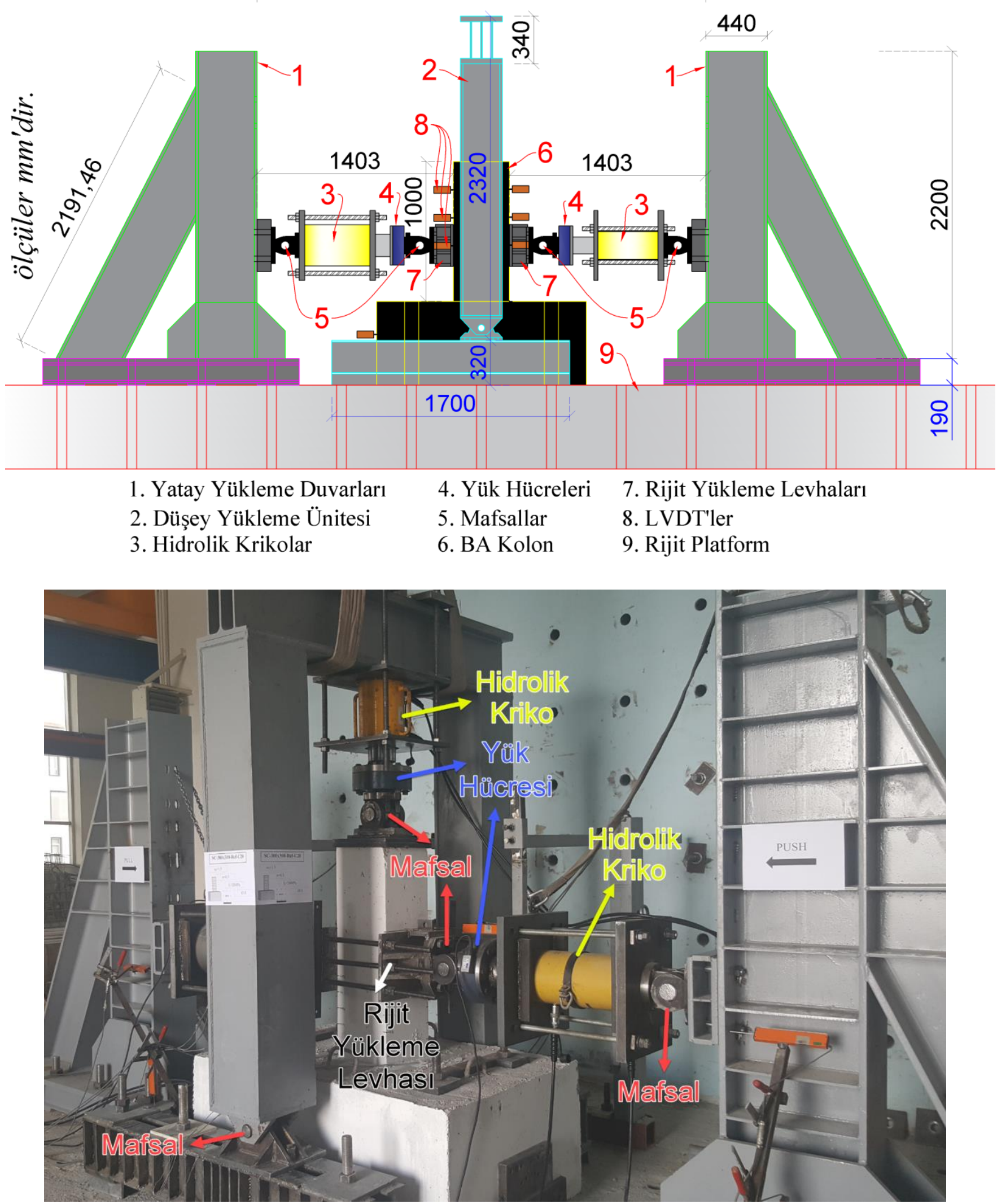

Şekil 3. Deney düzeneğinin görünümü 


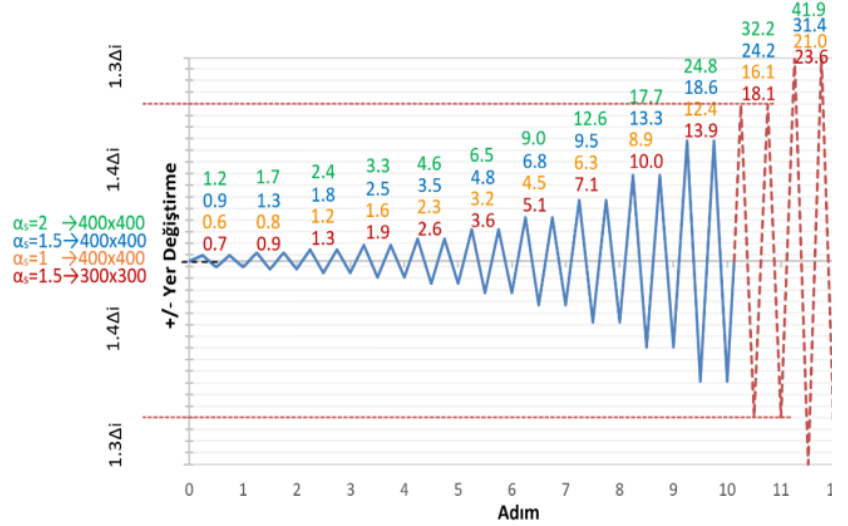

Şekil 4. Yükleme prosedürü yer değiştirme-adım grafiği

dayanımı ifadelerinde kolonların kesme açıklı̆ğ oranları dikkate alınmamaktadır. Tasarıma yönelik hesaplamalarda bazı malzeme katsayılarının kullanılması öngörülse de; bu çalışma kapsamında kullanılan malzemelerin dayanımları deneysel olarak belirlendiğinden, kesme kapasitesi hesaplamalarında malzeme katsayısı kullanılmamıştır.

\subsubsection{Basitleş̧tirilmiş değiştirilmiş basınç alanı teorisi modeli}

BA elemanların kesme dayanımını tahmin etmek için bir diğer alternatif, basınç alanları teorisinin basitleştirilmiş bir versiyonu olan ve çeşitli standart ya da yönetmeliklerde önerilen SMCFT [8] modelidir. SMCFT maksimum dayanımda basınç ve çekme gerilmeleri eğiminin hesaplanmasını sağlayan basit denklemlerle orijinal teoriyi [7] basitleştirir. Hem enine hem de boyuna donatılandırılmış betonun plastik bir kafes mekanizması ile olası farklı asal basınç açıları için kesme dayanımını dikkate alır. Çalışma kapsamında BA elemanların kesme dayanımlarının hesaplanmasinda SMCFT modelini esas alan CSA.A23.3-19 göz önüne alınmıştır.

\subsubsection{Dayanım azalması modelleri (Kesme dayanımı zarflarl)}

Deneysel bulgular [11-13] kesme hakim davranış sergileyen ya da iyi detaylandırılmamış BA elemanların düşük sünekliğe sahip olduğunu ve erkenden kesme kırılmasına maruz kaldığını göstermiştir. Döngüsel yükleme ve artan eğilme talebine bağlı deformasyonlar elemanın yatay tepkisini dolayısıyla kesme dayanımını önemli ölçüde etkilemektedir [14]. Artan süneklik talebine bağlı olarak kesme dayanımının azalması, sünek eğilme kırılması modunu akmanın gerçekleşmesinden sonraki yatay yük kapasitesinin ani bir şekilde düştüğü tehlikeli ve gevrek kesme kırılması moduna dönüştürebilir. Bu sebeple geniş deneysel bulgulara dayanan, çevrimsel yükleme ve artan süneklik talebine bağlı olarak dayanım azalmasını dikkate alan modern kesme dayanımı zarfi (KDZ) modelleri önerilmiștir. Bu çalıșma kapsamında bazı yönerge ve yönetmeliklerde de dikkate alınan Kowalsky ve Priestley [17], Biskinis vd. [2] ile Sezen ve Moehle [19] tarafindan önerilen kesme dayanımı zarfi modelleri göz önüne alınmıștır.

\section{Bulgular ve tartışma}

$\mathrm{Bu}$ çalışmada çevrimsel yükleme ve sabit eksenel yük etkisi altında testleri gerçekleştirilen on iki adet BA kolonun deneysel olarak elde edilen yatay yük dayanımları ile göz önüne alınan yedi kesme dayanımı hesap modelinden elde edilen kapasite sonuçları kıyaslanmıştır. Deneysel bulguları değerlendirmeye alınan kolonlar farklı kesme açıklı̆̆ oranları, beton dayanımları ve eksenel yük indekslerine sahip olduklarından, bu parametrelerin hesap modellerinin tahmini üzerindeki etkileri incelenmiștir.

\subsection{Test kolonlarinin dayanim zarflart}

Test kolonlarının histeretik davranışları ve dayanım zarfları Şekil 5-6'da verilmektedir. Kolonların akma noktaları (๑), tepe yükü noktaları (๑) ve göçme noktaları ( $\square)$ dayanım zarfları üzerinde işaretlenmiştir. Kolonların göçme noktaları, tepe yükünden sonraki $\% 80 \mathrm{~V}_{\text {mak }}$ seviyesine kadar değerlendirilmiştir. Göçme noktaları aynı zamanda kolonların performans seviyelerinin değerlendirildiği noktadır. Performans değerlendirmelerinde göçme noktalarının ötesindeki davranış dikkate alınmamıştır.

\subsection{Kesme dayanımı modellerinin sonuçları}

Kolonların yatay yük dayanımları itme ve çekme yüklemelerinde birbirine yakın olsa da, malzemenin anizotrop yapısı, kesit boyutları ve detaylarının kusursuz olamaması, çatlak gelişimleri vb. kontrol altına alınamayan nedenlerden ötürü farkl1lık göstermektedir. $\mathrm{Bu}$ nedenle kolon dayanımlarının net ve tek bir değer üzerinden kesme modelleri ile karşılaştırılabilmesi için, kolonların dayanımları itme-çekme yüklemelerinden elde edilen Vmak değerlerinin ortalaması olarak göz önüne alınmıştır. $\mathrm{Bu}$ noktada kolonların davranışlarında ve yatay yük dayanımlarında moment etkisinin de söz konusu olduğunu belirtmek gerekir. Yönetmelik modelleri salt kesme davranışını dikkate alırken, KDZ modelleri deneysel verilerle oluşturulduklarından düktilite talebindeki artışı esas alarak gayri ihtiyari olarak eğilme davranışını da dikkate alabilmektedir.

Kısım 2.4.1 ve 2.4.2'de tanımlanan kesme dayanımı modellerinde kesit için tek bir kesme dayanımı elde edilmektedir. Bu modeller için ilgili amprik ifadelerinden elde edilen kesme dayanımları esas alınmıştır. 2.4.3'de tanımlanan dayanım azalması modelleri ise düktilitiye bağlı olarak azalan kesme dayanımı zarfları ile tanımlanmaktadır. $\mathrm{Bu}$ modellerden elde edilen kesme dayanımları; dayanım zarfı ile kesme dayanımı zarfının kesişme noktası ya da (dayanım zarfı ile kesme dayanımı zarfı kesişmiyorsa) dayanım zarfının tepe noktasındaki düktilite değerine karşılık gelen kesme dayanımı zarfı değeri olarak dikkate alınmıştır. Kolonların ortalama dayanımları ile kesme dayanımı modellerinden elde edilen sonuçlar Tablo 2'de sayısal olarak, Şekil 7 ve Şekil 9'da ise görsel olarak özetlenmektedir. Değerlendirmelerde ACI $\rightarrow$ ACI 318-19'u, $\mathrm{TS} \rightarrow \mathrm{TS} 500 / 2000$ 'i, $\quad$ CSA $\rightarrow$ CSA.A23.3-19'u, B$\mathrm{SY} \rightarrow$ Biskinis-Stirrup $\quad$ Yielding, $\quad \mathrm{B}-\mathrm{WC} \rightarrow$ Biskinis-Web Crushing, $\quad \mathrm{KP} \rightarrow$ Kowalsky\&Priestley ve $\mathrm{SM} \rightarrow$ Sezen\&Moehle dayanım modellerini tarif etmek için kullanılmıştır. 
$\mathrm{BK}_{1}-(2)-\mathrm{C} 25-0.2-(\varnothing 10)$

(-) Normal Kat Yüksekliğine Göre Drift (\%)

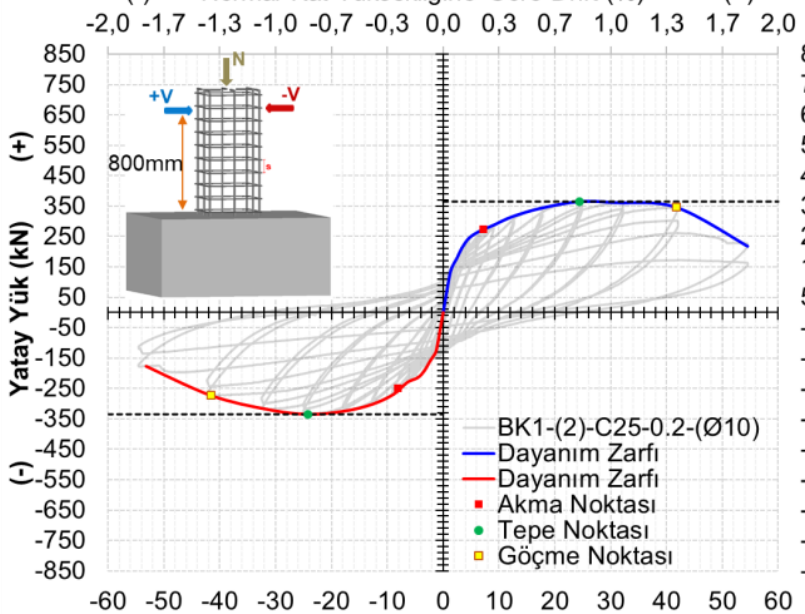

(-) Yatay Yer Değiştirme (mm) (+)

$+$

$\mathrm{BK}_{1}-(2)-\mathrm{C} 25-0.2-(\varnothing 12)$

$(-) \quad$ Normal Kat Yüksekliğine Göre Drift (\%)

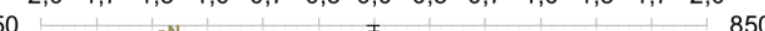

\begin{tabular}{ll|l|l|l|l|}
850 & 850 & $\mathbb{I}^{\mathrm{N}}$ & 圭 & 850 \\
750 & 750 & & 750
\end{tabular}

$650650 \quad+\mathrm{v}$

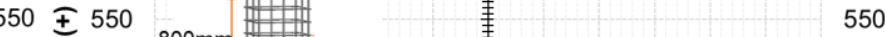

$450450800 \mathrm{~mm}$ \#靕 $\quad 450$

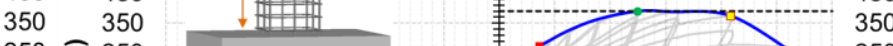

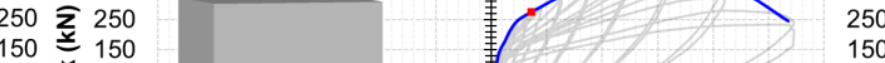

$50>50$

-150 突 -150

$-250 \stackrel{\pi}{\succ}-250$

$-350-350$

$-450-450$

$-550 \simeq-550$

$-650-650$

$-750-750$

$-850 \quad-850$

$\mathrm{BK}_{1}-(1.5)-\mathrm{C} 25-0.2-(\varnothing 10)$

(-) Normal Kat Yüksekliğine Göre Drift (\%) (+)

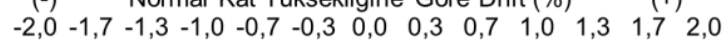

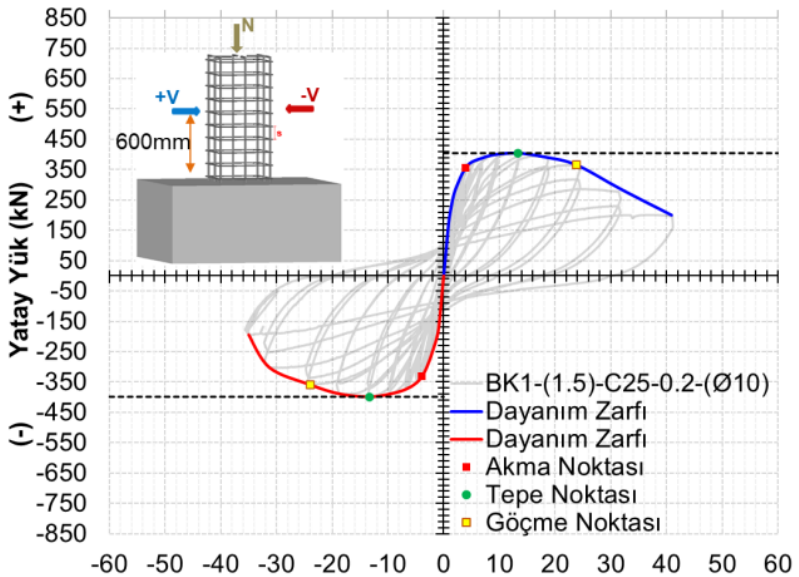

$(-) \quad$ Yatay Yer Değiştirme $(\mathrm{mm}) \quad(+)$

\author{
, 0
}

850

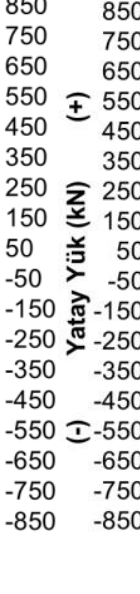

\section{$\mathrm{BK}_{1}-(1)-\mathrm{C} 25-0.2-(\varnothing 10)$}

$(-) \quad$ Normal Kat Yüksekliğine Göre Drift (\%)

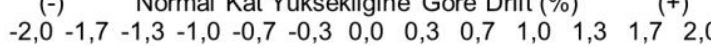

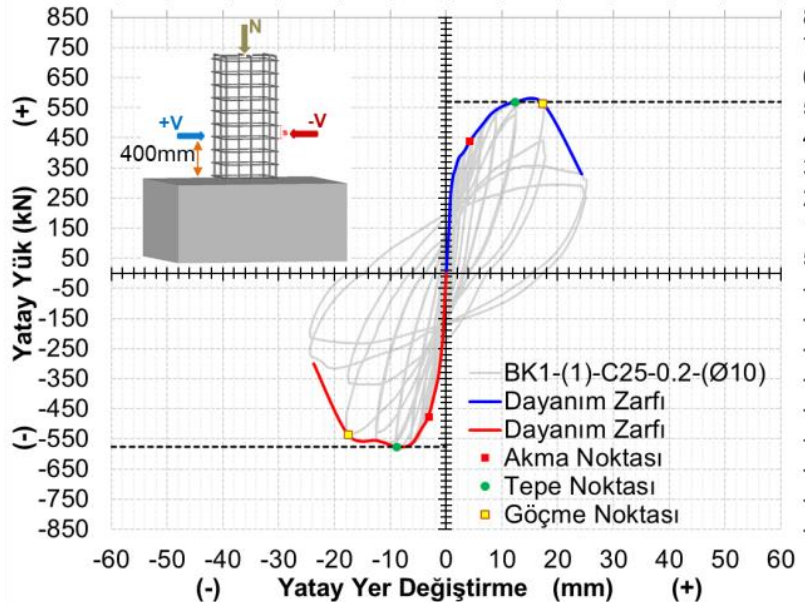

$\mathrm{BK}_{1}-(1.5)-\mathrm{C} 25-0.2-(\varnothing 12)$

$(-) \quad$ Normal Kat Yüksekliğine Göre Drift (\%) $(+)$

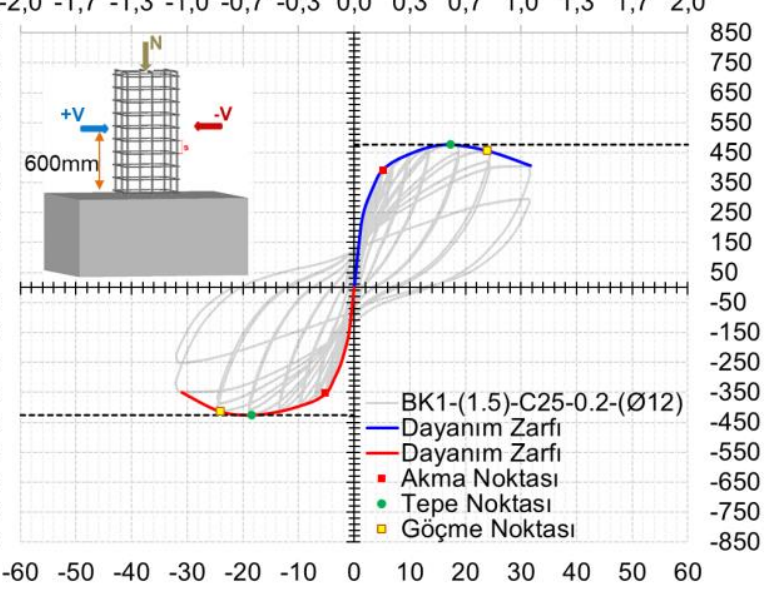

$(-) \quad$ Yatay Yer Değiştirme $\quad(\mathrm{mm}) \quad(+)$
$(-) \quad$ Normal Kat Yüksekliğine Göre Drift (\%) (+)

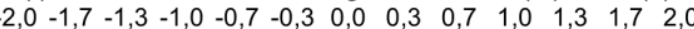

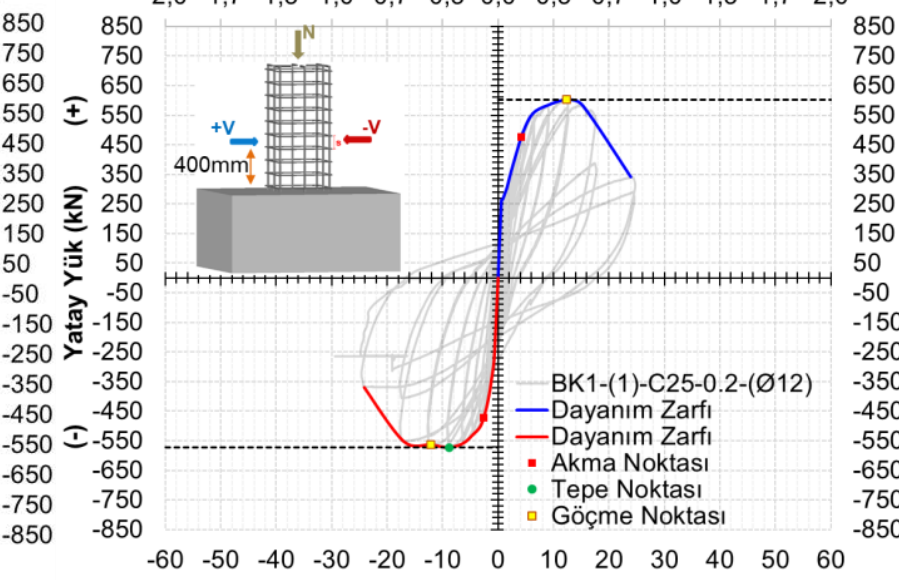

$(-) \quad$ Yatay Yer Değiştirme $\quad(\mathrm{mm}) \quad(+)$

Şekil 5. Grup 1 test kolonlarının histeresis eğrileri ve dayanım zarfları 


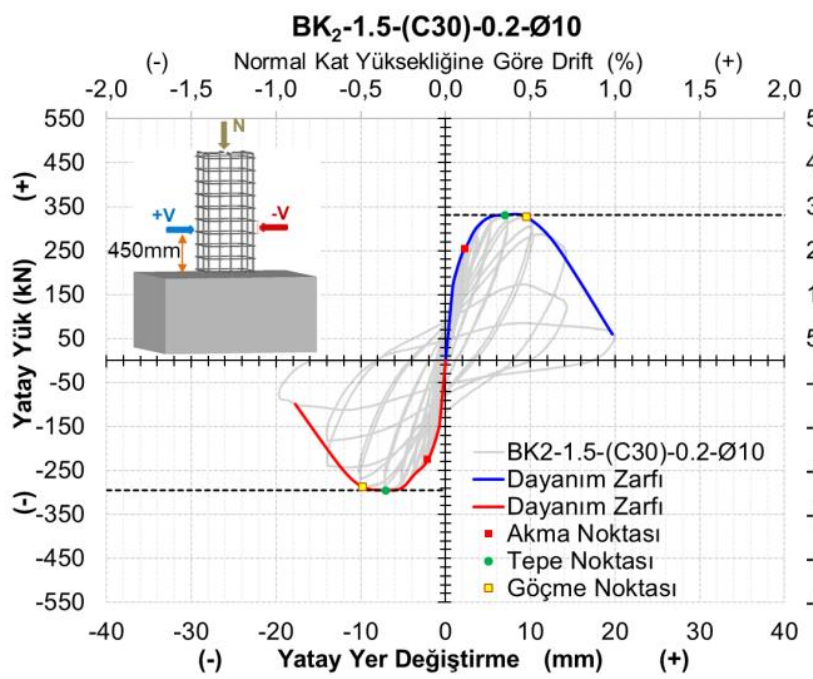

$\mathrm{BK}_{2}-1.5-(\mathrm{C} 40)-0.2-\varnothing 10$

(-) Normal Kat Yüksekliğine Göre Drift (\%)

$(+)$

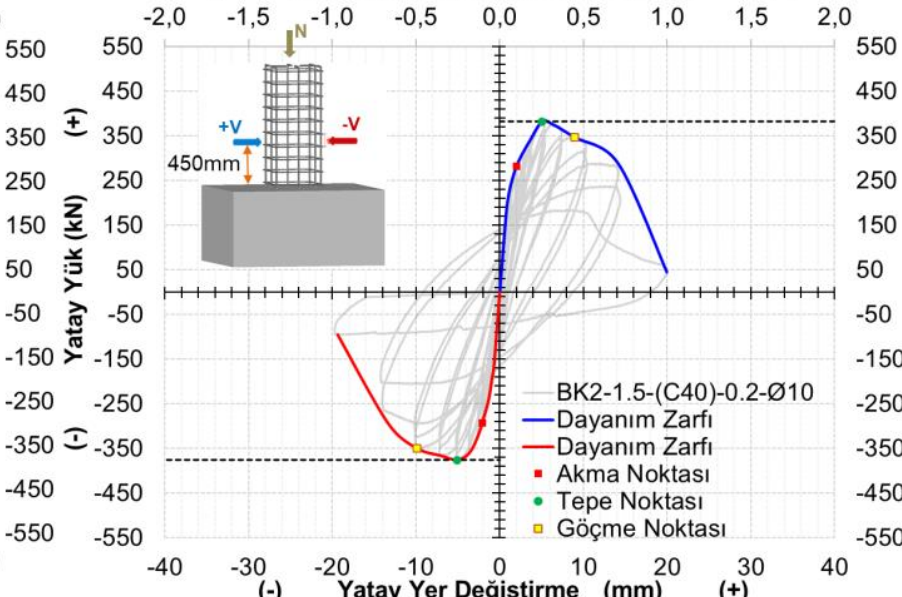

$\mathrm{BK}_{2}-1.5-(\mathrm{C} 50)-0.2-\varnothing 10$

$\begin{array}{lllllll}(-) & \text { Normal Kat Yüksekliğine Göre Drift (\%) } & \left({ }^{(+)}\right. \\ -1,5 & -1,0 & -0,5 & 0,0 & 0,5 & 1,0 & 1,5\end{array}$

$\mathrm{BK}_{2}-1.5-\mathrm{C} 20-(0.3)-\varnothing 10$

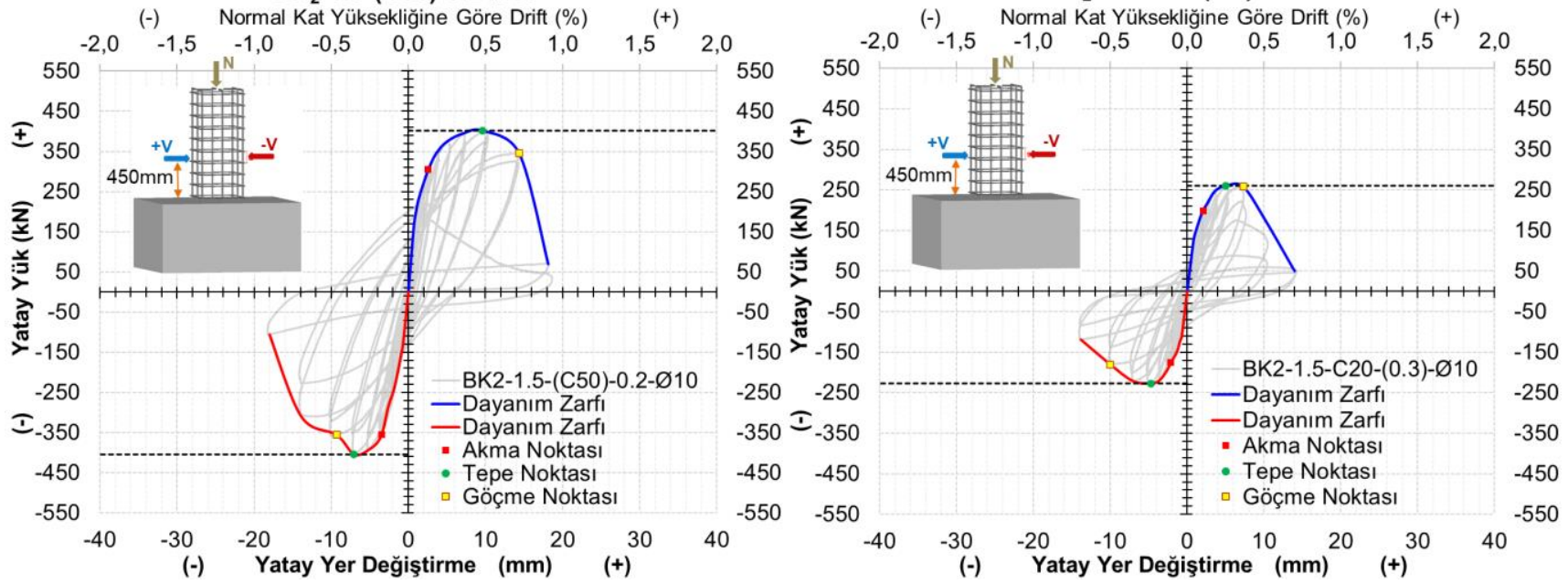

$\mathrm{BK}_{2}-1.5-\mathrm{C} 20-(0.4)-\varnothing 10$

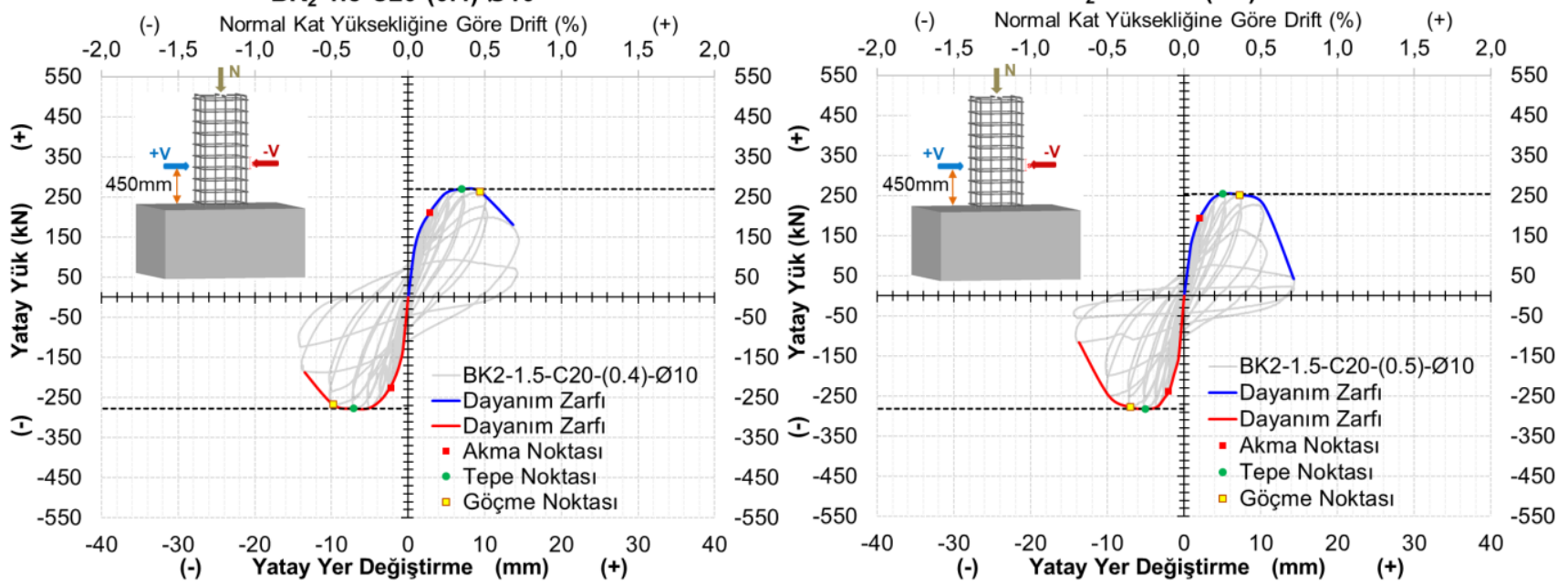

Şekil 6. Grup 2 test kolonlarının histeresis eğrileri ve dayanım zarfları 
Tablo 2. Test kolonlarının yatay yük dayanımları ve kesme dayanımı modellerinden elde edilen kapasite bulguları

\begin{tabular}{|c|c|c|c|c|c|c|c|c|}
\hline Kolon & $\begin{array}{l}\text { Ortalama } \\
\text { Deneysel } \\
\text { Dayanım }\end{array}$ & $\begin{array}{c}\text { Biskinis- } \\
\text { Web } \\
\text { Crushing } \\
\text { (B-WC) } \\
\text { kN }\end{array}$ & $\begin{array}{l}\text { Biskinis- } \\
\text { Stirrup } \\
\text { Yielding } \\
\text { (B-SY) } \\
\text { kN }\end{array}$ & $\begin{array}{c}\text { Kowalsky \& } \\
\text { Priestley } \\
\text { (KP) } \\
\text { kN }\end{array}$ & $\begin{array}{c}\text { Sezen } \\
\& \\
\text { Moehle } \\
(\mathrm{SM}) \\
\text { kN }\end{array}$ & $\begin{array}{c}\text { CSA- } \\
\text { AASHTO } \\
\text { (CSA) } \\
\text { kN }\end{array}$ & $\begin{array}{c}\text { ACI-318 } \\
\text { (ACI) } \\
\mathrm{kN}\end{array}$ & $\begin{array}{c}\text { TS500 } \\
\text { (TS) }\end{array}$ \\
\hline & $\mathrm{kN}$ & $\{\mathrm{A} / \mathrm{D}\}$ & $\{\mathrm{A} / \mathrm{D}\}$ & $\{\mathrm{A} / \mathrm{D}\}$ & $\begin{array}{c}\mathrm{kN} \\
\{\mathrm{A} / \mathrm{D}\}\end{array}$ & $\begin{array}{l}\mathrm{kN} \\
\{\mathrm{A} / \mathrm{D}\}\end{array}$ & $\begin{array}{l}\mathrm{kN} \\
\{\mathrm{A} / \mathrm{D}\}\end{array}$ & $\{\mathrm{A} / \mathrm{D}\}$ \\
\hline $\mathrm{BK}_{1}-(2)-\mathrm{C} 25-0.2-(\varnothing 10)$ & 349.88 & $\begin{array}{l}344.73 \\
\{0.99\}\end{array}$ & $\begin{array}{l}363.32 \\
\{1.04\}\end{array}$ & $\begin{array}{l}376.74 \\
\{1.08\}\end{array}$ & $\begin{array}{r}406.92 \\
\{1.16\}\end{array}$ & $\begin{array}{l}523.35 \\
\{1.50\}\end{array}$ & $\begin{array}{l}489.56 \\
\{1.40\}\end{array}$ & $\begin{array}{l}501.59 \\
\end{array}$ \\
\hline $\mathrm{BK}_{1}-(2)-\mathrm{C} 25-0.2-(\varnothing 12)$ & 377.77 & $\begin{array}{l}348.59 \\
\{0.92\}\end{array}$ & $\begin{array}{l}412.03 \\
\{1.09\}\end{array}$ & $\begin{array}{l}447.08 \\
\{1.18\}\end{array}$ & $\begin{array}{l}509.52 \\
\{1.35\}\end{array}$ & $\begin{array}{l}657.87 \\
\{1.74\}\end{array}$ & $\begin{array}{l}592.66 \\
\{1.57\}\end{array}$ & $\begin{array}{l}604.70 \\
\{1.60\}\end{array}$ \\
\hline $\mathrm{BK}_{1}-(1.5)-\mathrm{C} 25-0.2-(\varnothing 10)$ & 401.50 & $\begin{array}{l}434.00 \\
\{1.08\}\end{array}$ & $\begin{array}{l}401.92 \\
\{1.00\}\end{array}$ & $\begin{array}{l}454.66 \\
\{1.13\}\end{array}$ & $\begin{array}{l}515.35 \\
\{1.28\}\end{array}$ & $\begin{array}{l}523.35 \\
\{1.30\}\end{array}$ & $\begin{array}{l}489.56 \\
\{1.22\}\end{array}$ & $\begin{array}{l}501.59 \\
\{1.25\}\end{array}$ \\
\hline $\mathrm{BK}_{1}-(1.5)-\mathrm{C} 25-0.2-(\varnothing 12)$ & 451.40 & $\begin{array}{l}436.95 \\
\{0.97\}\end{array}$ & $\begin{array}{l}468.15 \\
\{1.04\}\end{array}$ & $\begin{array}{l}520.19 \\
\{1.15\}\end{array}$ & $\begin{array}{l}580.73 \\
\{1.29\}\end{array}$ & $\begin{array}{l}657.87 \\
\{1.46\}\end{array}$ & $\begin{array}{l}592.66 \\
\{1.31\}\end{array}$ & $\begin{array}{l}604.70 \\
\{1.34\}\end{array}$ \\
\hline $\mathrm{BK}_{1}-(1)-\mathrm{C} 25-0.2-(\varnothing 10)$ & 572.75 & $\begin{array}{l}581.02 \\
\{1.01\}\end{array}$ & $\begin{array}{l}495.19 \\
\{0.86\}\end{array}$ & $\begin{array}{l}543.59 \\
\{0.95\}\end{array}$ & $\begin{array}{l}698.86 \\
\{1.22\}\end{array}$ & $\begin{array}{l}523.35 \\
\{0.91\}\end{array}$ & $\begin{array}{l}489.56 \\
\{0.85\}\end{array}$ & $\begin{array}{l}501.59 \\
\{0.88\}\end{array}$ \\
\hline $\mathrm{BK}_{1}-(1)-\mathrm{C} 25-0.2-(\varnothing 12)$ & 587.32 & $\begin{array}{l}583.41 \\
\{0.99\}\end{array}$ & $\begin{array}{l}559.33 \\
\{0.95\}\end{array}$ & $\begin{array}{l}586.65 \\
\{1.00\}\end{array}$ & $\begin{array}{l}750.46 \\
\{1.28\}\end{array}$ & $\begin{array}{l}657.87 \\
\{1.12\}\end{array}$ & $\begin{array}{l}592.66 \\
\{1.01\}\end{array}$ & $\begin{array}{l}604.70 \\
\{1.03\}\end{array}$ \\
\hline $\mathrm{BK}_{2}-1.5-(\mathrm{C} 30)-0.2-\varnothing 10$ & 313.11 & $\begin{array}{l}321.99 \\
\{1.03\}\end{array}$ & $\begin{array}{l}341.90 \\
\{1.09\}\end{array}$ & $\begin{array}{l}331.51 \\
\{1.06\}\end{array}$ & $\begin{array}{l}366.22 \\
\{1.17\}\end{array}$ & $\begin{array}{l}362.99 \\
\{1.16\}\end{array}$ & $\begin{array}{l}329.63 \\
\{1.05\}\end{array}$ & $\begin{array}{l}336.67 \\
\{1.08\}\end{array}$ \\
\hline $\mathrm{BK}_{2}-1.5-(\mathrm{C} 40)-0.2-\varnothing 10$ & 379.03 & $\begin{array}{l}350.48 \\
\{0.92\}\end{array}$ & $\begin{array}{l}373.28 \\
\{0.98\}\end{array}$ & $\begin{array}{l}368.33 \\
\{0.97\}\end{array}$ & $\begin{array}{l}366.37 \\
\{0.97\}\end{array}$ & $\begin{array}{l}370.79 \\
\{0.98\}\end{array}$ & $\begin{array}{l}340.94 \\
\{0.90\}\end{array}$ & $\begin{array}{l}348.71 \\
\{0.92\}\end{array}$ \\
\hline $\mathrm{BK}_{2}-1.5-(\mathrm{C} 50)-0.2-\varnothing 10$ & 403.00 & $\begin{array}{l}377.67 \\
\{0.94\}\end{array}$ & $\begin{array}{l}395.02 \\
\{0.98\}\end{array}$ & $\begin{array}{l}391.67 \\
\{0.97\}\end{array}$ & $\begin{array}{l}423.71 \\
\{1.05\}\end{array}$ & $\begin{array}{l}383.06 \\
\{0.95\}\end{array}$ & $\begin{array}{l}358.73 \\
\{0.89\}\end{array}$ & $\begin{array}{l}367.64 \\
\{0.91\}\end{array}$ \\
\hline $\mathrm{BK}_{2}-1.5-\mathrm{C} 20-(0.3)-\varnothing 10$ & 243.71 & $\begin{array}{l}298.38 \\
\{1.22\}\end{array}$ & $\begin{array}{l}349.70 \\
\{1.43\}\end{array}$ & $\begin{array}{l}340.50 \\
\{1.40\}\end{array}$ & $\begin{array}{l}371.60 \\
\{1.52\}\end{array}$ & $\begin{array}{l}350.09 \\
\{1.44\}\end{array}$ & $\begin{array}{l}313.09 \\
\{1.28\}\end{array}$ & $\begin{array}{l}319.03 \\
\{1.31\}\end{array}$ \\
\hline $\mathrm{BK}_{2}-1.5-\mathrm{C} 20-(0.4)-\varnothing 10$ & 273.50 & $\begin{array}{l}322.03 \\
\{1.18\}\end{array}$ & $\begin{array}{l}370.22 \\
\{1.35\}\end{array}$ & $\begin{array}{l}362.88 \\
\{1.33\}\end{array}$ & $\begin{array}{l}381.52 \\
\{1.39\}\end{array}$ & $\begin{array}{l}350.09 \\
\{1.28\}\end{array}$ & $\begin{array}{l}322.34 \\
\{1.18\}\end{array}$ & $\begin{array}{l}328.73 \\
\{1.20\}\end{array}$ \\
\hline $\mathrm{BK}_{2}-1.5-\mathrm{C} 20-(0.5)-\varnothing 10$ & 267.74 & $\begin{array}{l}350.60 \\
\{1.31\}\end{array}$ & $\begin{array}{l}401.53 \\
\{1.50\}\end{array}$ & $\begin{array}{l}397.74 \\
\{1.49\}\end{array}$ & $\begin{array}{l}411.88 \\
\{1.54\}\end{array}$ & $\begin{array}{l}350.09 \\
\{1.31\}\end{array}$ & $\begin{array}{l}331.60 \\
\{1.24\}\end{array}$ & $\begin{array}{l}338.44 \\
\{1.26\}\end{array}$ \\
\hline
\end{tabular}

$\{A / D\}:$ Analitik/Deneysel

\subsubsection{Kesme açıklı̆̆ oranı ve kesme donatısı çapının etkisi}

Grup-1 kolonlarında kesme açıklığı oranları ve etriye çapları birer parametredir. Kesme açıklığı fazla olan kolonlarda eğilme davranışının daha etkili olmasından dolayı dayanım az, düktilite fazladır. Kesme açıklığı oranı azaldıkça kesme hakim davranış etkili olmaktadır. Kesme açıklığı oranı davranışta kesme etkileşimini artıran en önemli faktörlerden biridir. Kesme donatısı oranı ise kesitin kesme kapasitesini artıran bir parametredir. Şekil 7'de Grup-1 kolonlarının ortalama deneysel dayanımları ile kesme dayanımı modellerinden elde edilen bulgular görsel olarak verilmektedir. $\alpha_{s}=2$ olan kolonlar eğilme hakim davranış sergilemişlerdir. ACI, TS ve CSA ampirik kesme kapasiteleri ortalama deneysel dayanımlardan $\varnothing 10$ etriyeye sahip kolonlarda 1.40-1.50, Ø12 etriyeye sahip kolonlarda ise 1.57-1.74 kat daha yüksektir. Yönetmelik modelleri ile belirlenen kesme değerlerinin deneysel dayanımın oldukça üzerinde olmasının nedeni, kolonların eğilme hakim davranış sebebiyle kesme kapasitelerine ulaşmamasıdır. KDZ modellerinden elde edilen sonuçlar ise $\varnothing 10$ etriyeye sahip kolonlarda 0.99-1.08, Ø12 etriyeye sahip kolonlarda 0.92-1.18 aralığındadır. $\alpha_{s}=2$ için B-WC, B-SY ve KP modellerinin öngörüleri deneysel bulgularla oldukça uyumlu sonuçlar vermiştir.

$\alpha_{s}=1.5$ olan kolonlarda; ACI, TS ve CSA modellerinin sonuçlarının deneysel dayanıma oranı azalarak Ø10 ve Ø12 etriyeye sahip kolonlar için sırasıyla 1.22-1.30 ve 1.31-1.46 olmuştur. $400 \times 400 \mathrm{~mm}^{2}$ en kesite sahip bu kolonlarda da güç tükenmesi eğilmenin hakim olduğu bir davranış sonucunda gerçekleşmiştir. Ancak yönetmelik modelleri ile deneysel dayanım oranlarının azalması davranışta kesme etkileşiminin arttığını göstermektedir. KDZ modellerinden elde edilen oranlar ise $\varnothing 10$ ve $\varnothing 12$ etriyeli kolonlar için sırasıyla 1.00-1.28 ve 0.97-1.29 aralığında değişmektedir. BWC, B-SY ve KP modellerine ait öngörülerin kesme davranışını tahmini ve belirlediği dayanım zarfı sınırları deneysel davranışla oldukça uyumludur. Kesme açıklığı oranının azalması SM modelinin kesme dayanımı zarfı sınırlarını yönetmelik öngörülerinin seviyesine çekmiştir.

$\alpha_{s}=1$ olan kolonlarda; ACI, TS ve CSA modellerinin sonuçları $\mathrm{BK}_{1}-\varnothing 10$ kolonu için ortalama deneysel dayanım verilerinin altına düşmüştür. $\mathrm{BK}_{1}-\varnothing 12$ kolonu ise yönetmelik modellerinin belirlediği kesme kapasitesi sınırındadır. $\mathrm{Bu}$ modellerden elde edilen sonuçların ortalama deney dayanımlarına oranı Ø10 ve Ø12 etriyeye sahip kolonlar için sırasıyla 0.85-0.91 ve 1.01-1.12 aralığındadır. Yönetmelik modelleri tasarıma yönelik olduğundan, kesme dayanımlarının belirlenmesinde oldukça ihtiyatlıdır. Kesitin salt kesme dayanımının dikkate alındığı bu modellerde belirli bir güven aralığı da benimsenerek tehlikeli kesme kırılmasından uzaklaşmak amaçlanır. Dolayısıyla kesmenin hakim olduğu elemanlarda deneysel olarak belirlenen kesme dayanımının yönetmelik modellerinden daha yüksek olması beklenir. Nitekim $\mathrm{BK}_{1}-\varnothing 10$ kolonunun dayanımı yönetmelik modellerinden daha yüksektir. Ancak aradaki fark yönetmeliklerin dikkate aldığı güven aralığından küçüktür. Bunun yanı sıra $\mathrm{BK}_{1}-\varnothing 12$ kolonunun deneysel dayanımı ise yönetmelik modelleri ile belirlenen kapasite seviyesindedir ve söz konusu güven aralığı ortadan kalmıştır. Dolayısıyla 

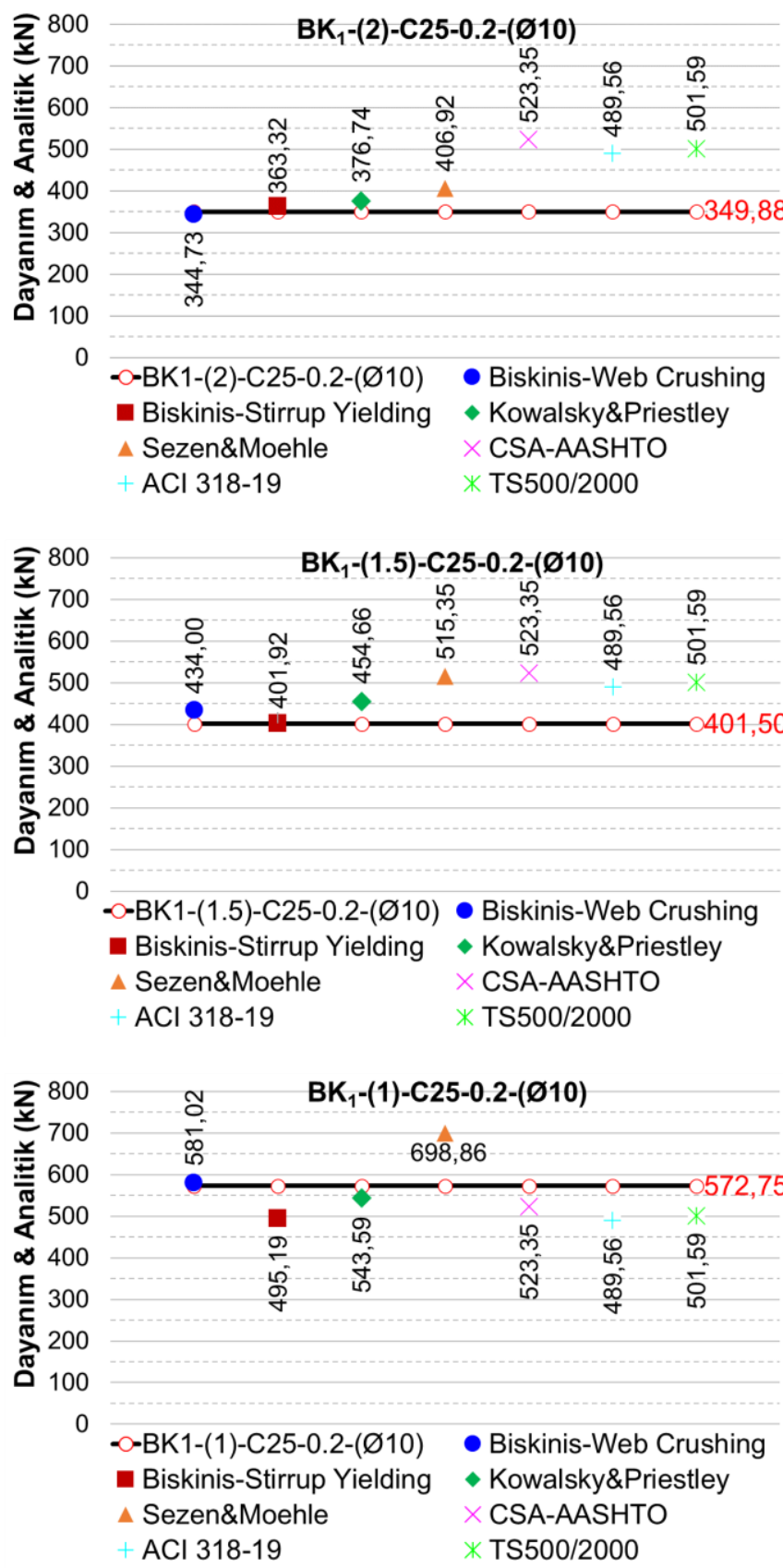
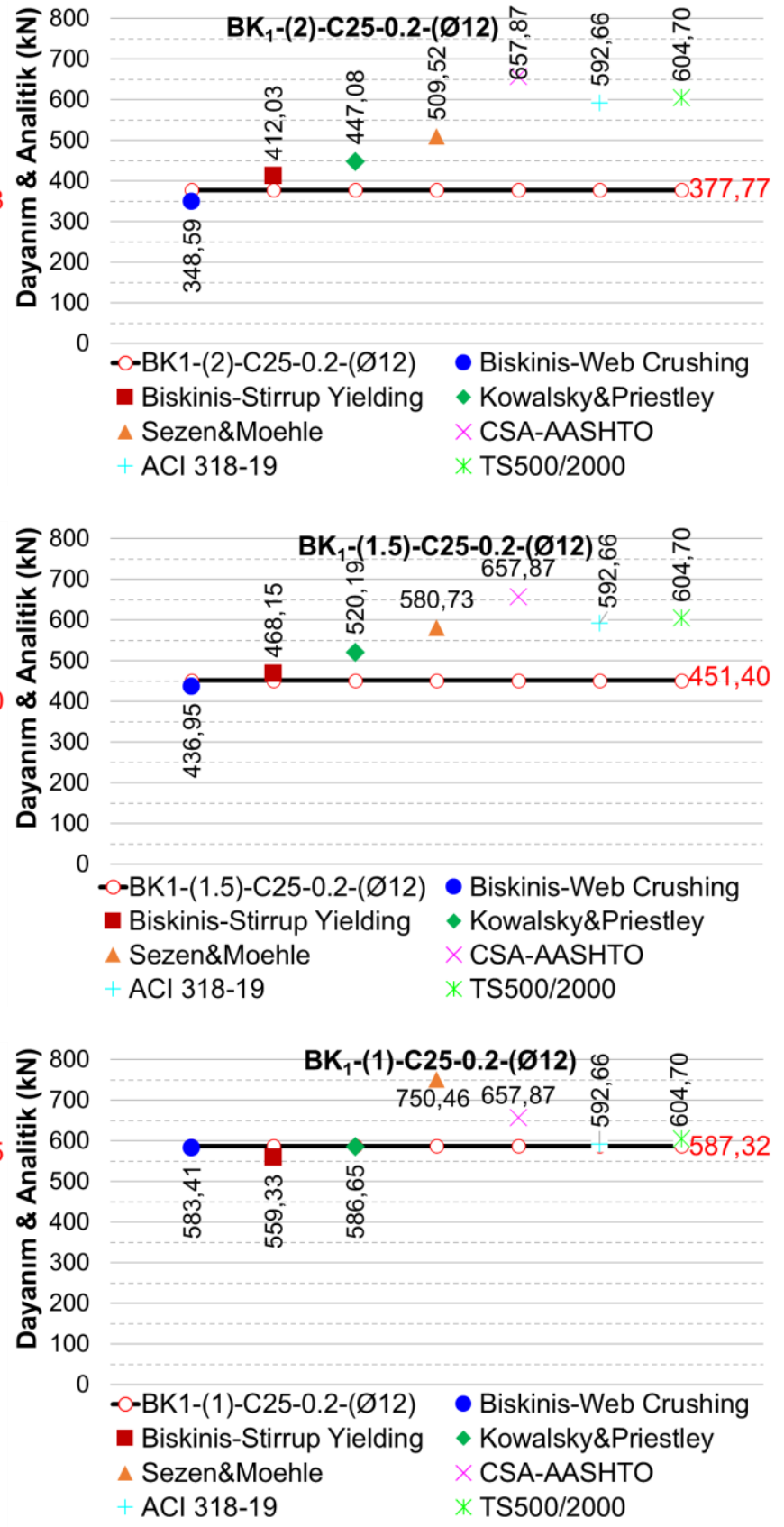

Şekil 7. Grup 1 test kolonlarının dayanımları ile kesme dayanımı modellerinin karşılaştırılması

kesitin güven aralığı dikkate alınmadan taşıyabileceği kesme kuvvetinin, başka bir deyişle kesitin gerçek kesme kapasitesinin daha yüksek olması ve kesitin kesme kırılmasına uğramaması beklenir. Ancak her iki kolon da kesme kırılması ile güç tükenmesine ulaşmıştır. Yönetmelik modellerinin güven aralıklarının azalması ya da ortadan kalkması çevrimsel yüklemenin bir sonucu olarak ortaya çıkmaktadır. Şu noktada kesmenin hakim olduğu elemanlar için tasarıma yönelik olarak kesitin kesme dayanımının belirlenmesinde çevrimsel yük etkisinin dikkate alınması, kesme davranışı beklenen elemanların kesme kırılmasına uğramamaları için elzem görülmektedir. KDZ modellerinden elde edilen sonuçların ortalama deneysel dayanımlara oranı Ø10 ve Ø12 etriyeye sahip kolonlar için sirasıyla $0.86-1.22$ ve $0.95-1.28$ aralığındadır. B-WC ve KP modellerinin oldukça başarılı olduğu, B-SY modelinin buna yakın bir başarı sergilediği görülmüştür. SM modeli kesme oranı 1 olan kolonların deneysel kesme dayanımlarının belirlenmesinde (bu çalışma kapsamında dikkate alınan kolonlar için) aynı başarıyı gösterememiştir.

Grup-1 kolonlarında kesme açıklığı oranının azalması davranıştaki kesme etkileşimini önemli ölçüde artırmıştır. KDZ modellerinin bu kesme etkileşiminin belirlenmesi için oluşturulan kesme dayanımı sınırlarının davranışı oldukça başarılı bir şekilde simüle ettiği görülmüştür. B-WC, B-SY ve KP modellerinin öngörüleri hem kesme açıklığı oranı ve hem de etriye çapının değişmesi durumunda deneysel dayanıma yakın sonuçlar vermiştir. Dolayısıyla gerek eğilme 
gerekse kesme hakim davranış sergileyen kolonların mevcut kesme kapasitelerinin analitik olarak belirlenmesinde bu modellerin kullanılması tavsiye edilebilir. Ancak bu modellerin özellikle kesme kritik elemanlarda tasarıma yönelik olarak kullanılması için bir güven aralığına ihtiyaç duyulmaktadır. Şekil 8'de Grup-1 kolonlarının deneysel dayanım zarfları ile kesme dayanımı zarfları birlikte verilmektedir.

\subsubsection{Beton dayanımı ve eksenel yük indeksinin etkisi}

Grup-2 kolonlarında beton dayanımları ve eksenel yük indeksleri birer parametredir. Beton dayanımının ve eksenel yük indeksinin artması kolonların yatay tepkilerinin artmasına neden olmuştur. Beton dayanımının artması kolonların dayanımlarının artmasında eksenel yüke göre daha etkili iken, eksenel yük indeksinin artması ise düktilitenin azalmasında etkili olmuştur. Dolayısıyla eksenel yük indeksindeki artış, yer değiştirme tepkisini azaltarak kesme hakim davranışın etkisini artırmıştır. Şekil 9'da Grup2 kolonlarının ortalama deneysel dayanımları ile kesme dayanımı modellerinden elde edilen bulgular görsel olarak verilmektedir.

Grup-2 BD serisi kolonlarda; ACI, TS ve CSA modellerinden elde edilen sonuçların deneysel dayanıma oranları 0.89-1.16 arasında değişmektedir. $400 \times 400 \mathrm{~mm}^{2}$ en kesite sahip Grup-1 kolonlarında $\alpha_{\mathrm{s}}=1.5$ için kesme kırılması meydana gelmezken, aynı kesme oranına sahip $300 \times 300 \mathrm{~mm}^{2}$ en kesitli Grup-2 kolonlarında kesme kırılmas meydana gelmiştir. Grup-1 kolonlarında en kesit alanının büyüklüğüne bağlı olarak kesme dayanımının fazla olması, elemanın kesme kapasitesine ulaşmadan eğilme dayanımına ulaşarak kırılmasına neden olmuştur. Bu durum yönetmelik modelleri ile belirlenen kapasitelerin deneysel dayanıma oranlarından da görülmektedir. Kolon en kesit alanının azalması, beton dayanımının artmasına rağmen $\alpha_{s}=1.5$ oranını kesme kırılması açısından kritik hale getirmiştir. BD serisinde yönetmelik modelleri ile belirlenen kapasiteler deneysel dayanım verilerine oldukça yakındır. Bu noktada yönetmeliklerin ihtiyatlı yaklaşımla benimsediği güven aralığı dikkate alınırsa, kesitin gerçek dayanımının daha büyük olması ve yönetmelik kapasitelerinin hemen yakınında kesme kırılmasına uğramaması beklenir. Ancak Grup-1 $\alpha_{\mathrm{s}}=1$ kolonlarında bahsedildiği gibi, çevrimsel yükleme ve artan yer değiştirme talebi bu kolonların kesme kırılmasına uğramasına neden olmuştur. Kesme kırılmaları akma sonrasında meydana gelmiştir. Bu durum çevrimsel yükleme altında akmadan sonra kesme dayanımının azaldığını ve bunun dikkate alınması gerektiğini doğrulamaktadır. KDZ modelleri BD serisi kolonların dayanımlarının belirlenmesinde oldukça başarılı olmuştur. KDZ modellerinden elde edilen analitik sonuçların deneysel dayanımlara oranları 0.92-1.17 arasında değişmektedir. BWC, B-SY, KP ve SM modelleri dayanımın belirlenmesi ve davranışın benzeştirilmesi açısından bu seride oldukça başarılı olmuştur.

Grup-2 n serisi kolonlarda; ACI, TS ve CSA modellerinden elde edilen sonuçların deneysel dayanımlara oranları 1.18-1.44 arasında değişmektedir. "n serisi” beton dayanımlarının diğerlerine göre düşük olması kesitin kesme dayanımını azaltan faktörlerden biridir. Ancak kolonlar ihtiyatlı sonuçlar veren yönetmelik modellerinden elde edilen kapasite değerlerine dahi ulaşmadan kesme kırılmasına uğramışlardır. Ayrıca şu noktaya kadar; gerek kesme oranı, gerek kesme donatısı alanı gerekse beton dayanımındaki değişime rağmen oldukça tutarlı sonuçlar veren KDZ modellerinin öngörüleri de deneysel dayanımların üzerinde kalmıştır. Bu noktada eksenel yük indeksinin etkisinin olduğu açıktır. "n serisi" kolonlarda dikkate alınan eksenel yük indeksleri için kolonun dayanımı fazla değişmezken, bu kolonların yer değiştirme cevapları BD serisine göre daha sınırlı kalmıştır. Çevrimsel yükleme altında artan yer değiştirme talebine cevap veremeyen kolonlar tahmin edilen kesme kapasitelerine ulaşamadan kesme kırılmasına uğramışlardır. Dolayısıyla gerek yönetmeliklerde gerekse KDZ modellerinde eksenel yükün kesmeye katkısının dikkate alınmasından çok, düktiliteyi azaltıcı yöndeki etkisinin dikkate alınması gerekliliği ortaya çıkmaktadır. Şekil 10'da Grup-2 kolonlarının deneysel dayanım zarfları ile kesme dayanımı zarfları birlikte verilmektedir.

\section{Sonuçlar}

Bu çalışmada sabit eksenel yük ve çevrimsel yatay yük altında test edilen BA kolonların yatay yük dayanımları ile hali hazırda kullanılan ya da yaygın olarak kabul gören kesme dayanımı modellerinden elde edilen kesme dayanımları karşılaştırılmıştır. Çevrimsel yük altında test edilen BA kolonların kesme dayanımlarının belirlenmesinde ele alınan kesme dayanımı modellerinin öngörüleri değerlendirilmiştir. $\mathrm{Bu}$ noktada testleri gerçekleştirilen kolonların güncel yönetmeliklerin tasarım koşullarını sağlayan kusursuz kolonlar olduğunu vurgulamak gerekir. Çalışmadan elde edilen sonuçlar şu şekilde sıralanabilir:

- ACI-318 ve TS500'de kafes analojisini esas alan hesaplarla belirlenen kesme dayanımları, SMCFT'yi esas alan CSA'dan elde edilen dayanımlardan küçüktür. Dolayısıyla ACI ve TS500 öngörüleri CSA'ya göre daha ihtiyatlı sonuçlar vermektedir.

- Kesme dayanımı zarfi modellerinden B-WC, B-SY ve KP modelleri deneysel dayanımın belirlenmesinde ve davranıştaki kesme etkileşiminin benzeştirilmesinde oldukça başarılı olmuştur.

- Yönetmeliklerde verilen tasarım esaslarından elde edilen sonuçların elemanın dayanımından daha düşük sonuçlar vermesi beklenir. Tasarım yapılırken mevcut kesit dayanımının belirli katsayılarla azaltılarak daha ihtiyatlı bir yaklaşım benimsenmesi ve tasarımın buna göre yapılması, tehlikeli olan kesme kırılmasının gerçekleşmemesi için bir güven aralığ1 oluşturur. Bunun yanı sıra kesit dayanımı salt kesme dayanımı olarak dikkate alınır. Dolayısıyla kesme hakim davranış sergileyen bir elemanın gerçek kesme dayanımının yönetmelik modellerinin öngördügüünün üzerinde olması beklenir. Nitekim bu durum kesme açıklığı oranı 1 olan kolonlarda görülmüştür. Ancak çevrimsel yük 

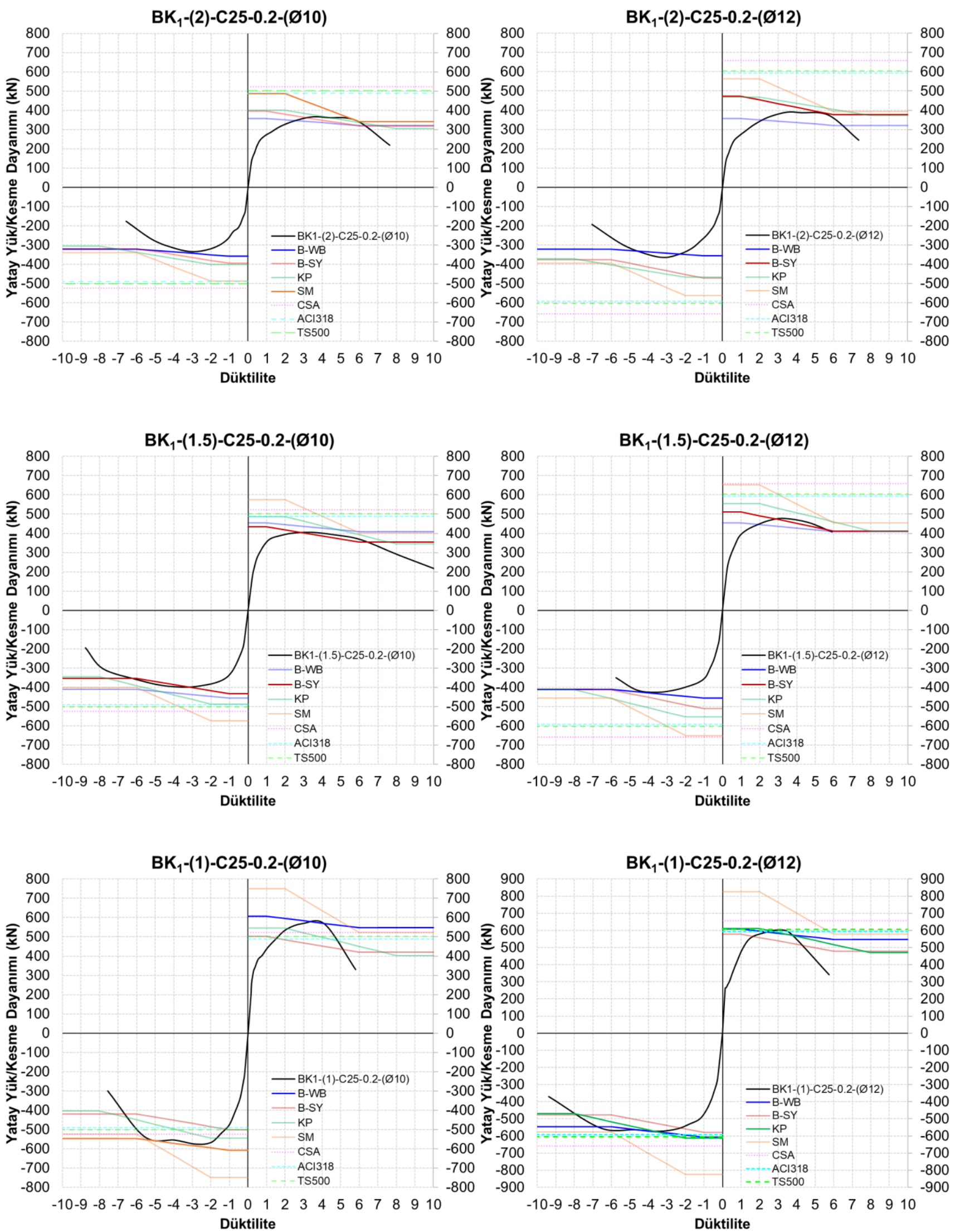

Şekil 8. Grup 1 kolonlarının dayanım zarfları ile kesme dayanımı zarflarının karşılaştırılması 


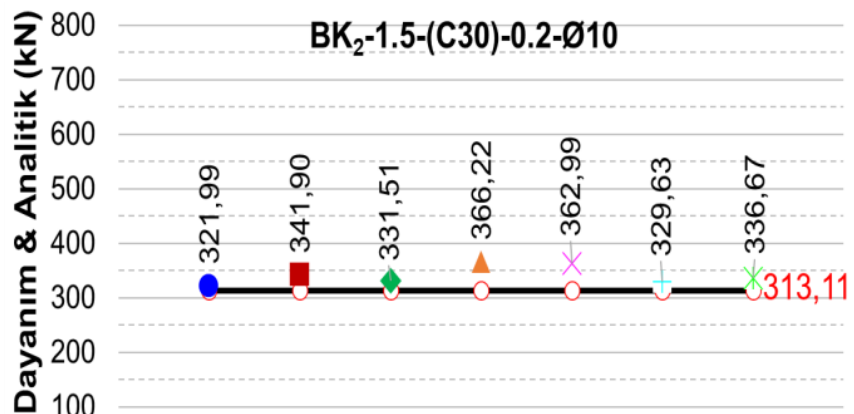

0

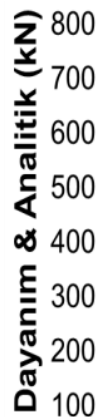

0

$\rightarrow B K 2-1.5-(C 40)-0.2-\varnothing 10$

- Biskinis-Stirrup Yielding

$\triangle$ Sezen\&Moehle

ACl 318-19
$\mathrm{BK}_{2}-1.5-(\mathrm{C} 40)-0.2-\varnothing 10$

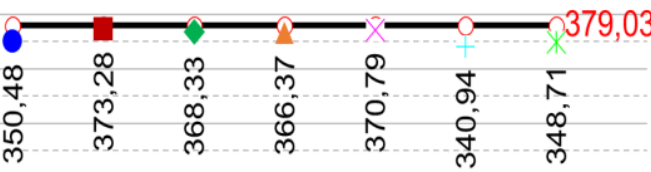

- Biskinis-Web Crushing

- Kowalsky\&Priestley

$\times$ CSA-AASHTO

* TS500/2000

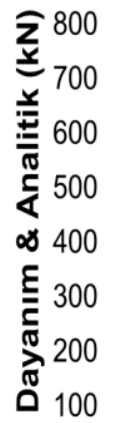

0

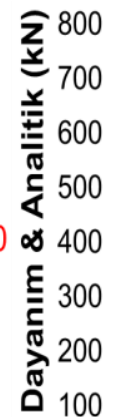

0

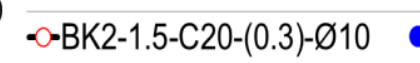
- Biskinis-Stirrup Yielding $\triangle$ Sezen\&Moehle ACl 318-19
$\mathrm{BK}_{2}-1.5-\mathrm{C} 20-(0.3)-\varnothing 10$

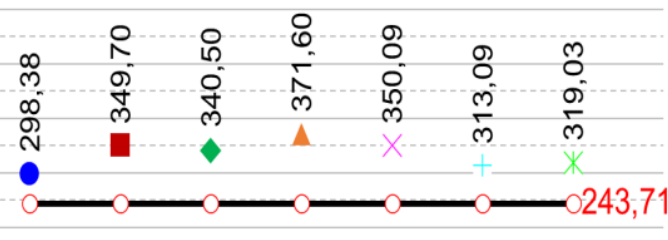

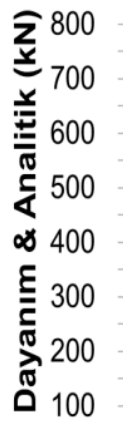

0

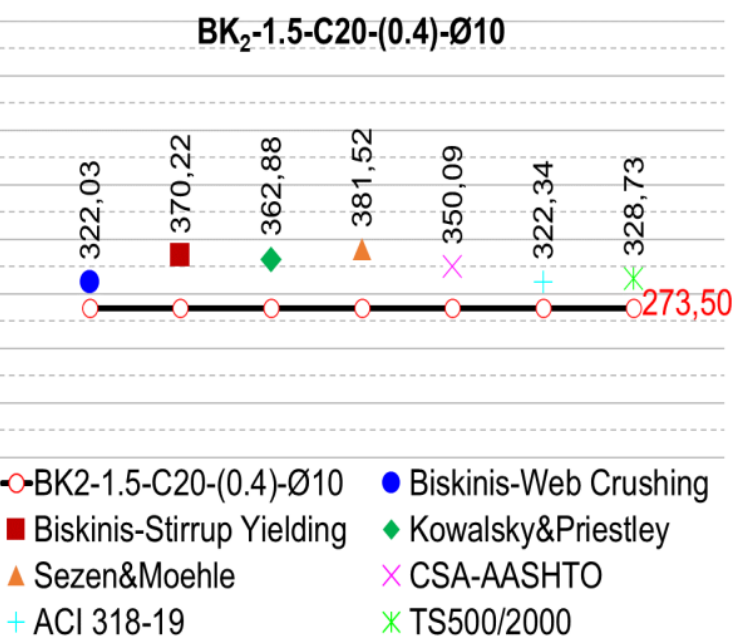

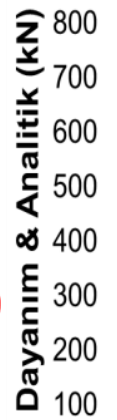

0

Şekil 9. Grup 2 test kolonlarının dayanımları ile kesme dayanımı modellerinin karşılaştırılması 

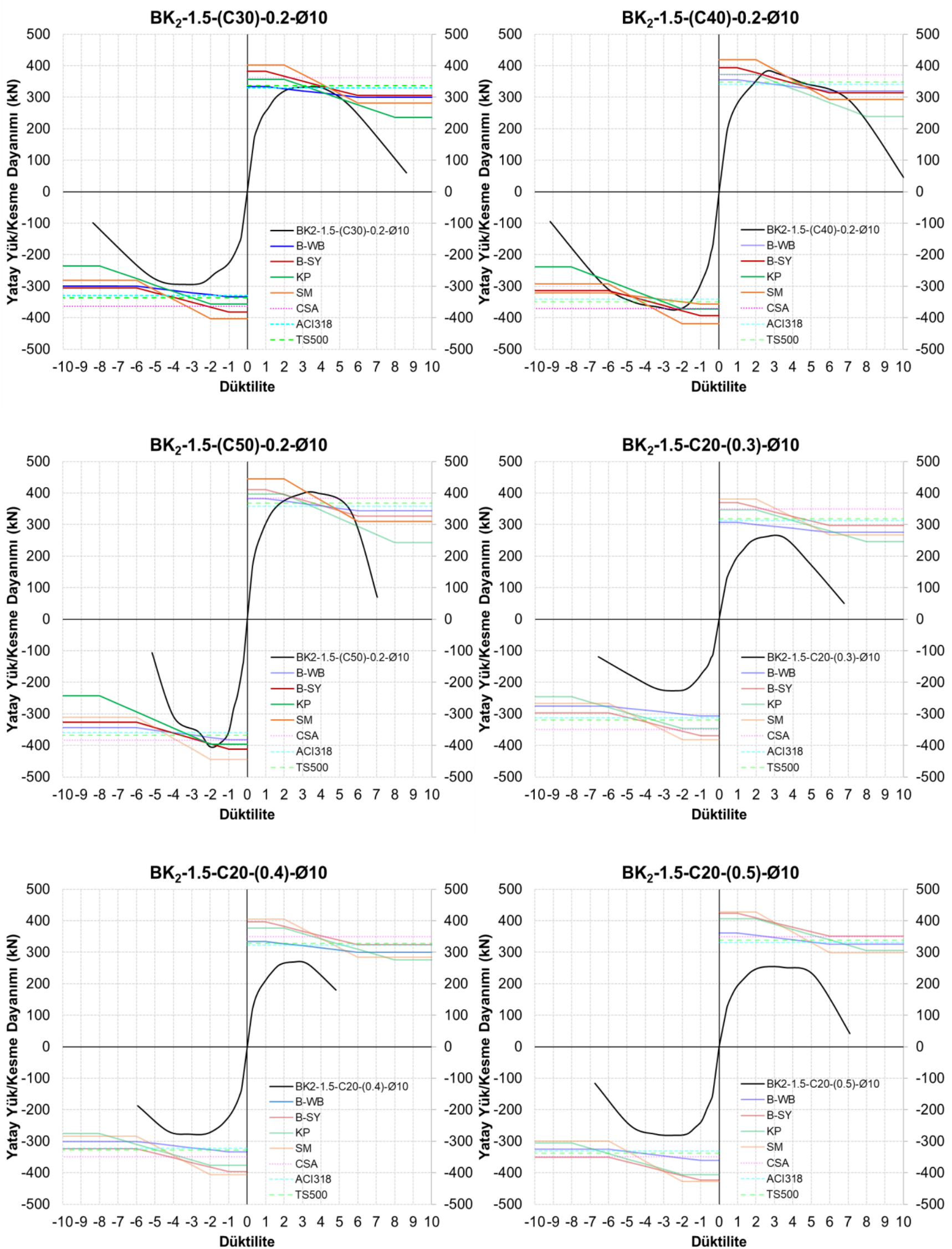

Şekil 10. Grup 2 kolonlarının dayanım zarfları ile kesme dayanımı zarflarının karşılaştırılması 
ve artan yer değiştirme talebi kesitin kesme dayanımını azaltmakta ve bahsedilen güven aralığının ortadan kalkmasına neden olmaktadır. Yönetmeliklerin güven aralığını koruyarak kesme dayanımı azalması modellerini göz önünde bulundurması ve bunu eğilme kapasitesi ile birlikte ele almak suretiyle tasarıma yönelmesi tavsiye edilebilir.

- En kesit boyutları Grup-1 kolonlarına göre küçük olan Grup-2 kolonlarında meydana gelen kesme kırılmaları, $\alpha_{s}=1.5$ seviyesinin de kesme açısından kritik olduğunu göstermiştir. Bu durum yeterli kesme donatısı detayına sahip olmayan kolonlarda $\alpha_{s}=2$ değerinin de kritik olabileceği fikrini uyandırmaktadır. Bu çalışma kapsamında dikkate alınan kolonlar yeterli kesme donatısı detayına sahip olduklarından, kesme kırılmaları akmadan sonra gerçekleşmiştir. Benzeri incelemelerin kesme donatısı oranı daha az ya da yetersiz olan kolonlar için de yapılması tavsiye edilebilir.

- Eksenel yük indeksi davranışın kesmeye yönlenmesinde oldukça etkilidir. Yönetmelik modelleri ve KDZ modellerinden elde edilen sonuçlara göre $n$ serisi kolonlarda kesme kırılması beklenmezken, bu kolonlar kesme kırılmasına uğramışlardır. Dolayısıyla gerek yönetmeliklerde gerekse KDZ modellerinde eksenel yükün kesmeye katkısının dikkate alınmasından çok, düktiliteyi azaltıcı yöndeki etkisinin dikkate alınması gerekliliği ortaya çıkmaktadır.

- Kesme dayanımı zarfı modelleri mevcut davranışın tahmininde oldukça başarılı olduklarından gerek eğilme gerekse kesme hakim davranış sergileyen kolonların mevcut kesme kapasitelerinin analitik olarak belirlenmesinde bu modellerin kullanılması tavsiye edilebilir. Ancak bu modellerin özellikle kesme kritik elemanlarda tasarıma yönelik olarak kullanılması için bir güven aralığına ihtiyaç duyulmaktadır.

- Kesme dayanımı modelleri kesitin özelliklerinden ve yük koşullarından yola çıkarak kesme davranışını benzeştirmektedir. Beklenen ötelenme ya da düktilite talebine göre kesitin kesme dayanımının tahmin edilmesinde başarılı oldukları da görülmüştür. Ancak bu zarflar kesitin kesme dayanımından yola çıkarak düktilite cevabının belirlenmesi için kullanılmamalıdır.

\section{Teșekkür}

$\mathrm{Bu}$ çalıșmanın deneysel çalıșmaları TÜBİTAK tarafindan 115M264 kodu ile desteklenen proje kapsamında ERÜ İnşaat Mühendisliği Bölümü yapı mekaniği laboratuvarında gerçekleştirilmiştir.

\section{Çıkar çatıșması}

Yazar çıkar çatışması olmadığını beyan etmektedir.

\section{Benzerlik oranı (iThenticate): $\% 5$}

\section{Kaynaklar}

[1] FEMA 274.NEHRP commentary on the guidelines for the seismic rehabilitation of buildings. Federal Emergency Management Agency. Applied Technology Council. Washington D.C., 1997.
[2] D.E. Biskinis. G.K. Roupakias and M.N. Fardis. Degradation of shear strength of reinforced concrete members with inelastic cyclic displacements. ACI Structural Journal. $101 \quad$ (6). 773-783. 2004. https://doi.org/10.14359/13452

[3] W. Ritter. Die bauweise hennebique Schweizerische Bauzeitung. 33. 59-61. 1899.

[4] E. Mörsch. Concrete-steel construction (English translation by E. P. Goodrich of the original manuscript of the 1902). New York: McGraw-Hill; 1909.

[5] F. De Luca and G.M. Verderame. A practice-oriented approach for the assessment of brittle failures in existing reinforced concrete elements Engineering Structures. 48. 373-388. 2013. https://doi.org/10.1016/ j.engstruct.2012.09.038

[6] R. Park and T. Paulay. Reinforced Concrete Structures. John Wiley \& Sons. Inc.; 1975.

[7] F. J. Vecchio and M. P. Collins. The Modified Compression-Field Theory for Reinforced Concrete elements subjected to shear, ACI Journal. 83(2), 219231. 1986. https://doi.org/10.14359/10416

[8] E. C. Bentz. F. J. Vecchio and M. P. Collins. Simplified modified compression field theory for calculating shear strength of reinforced concrete elements. ACI Structural Journal. 103 (4). 614-624. 2006. https://doi.org/10.14359/16438

[9] CSA. Standard A23.3-04. Concrete Design Handbook. Cement Association of Canada. Canada: 2006.

[10] AASHTO LRFD. Bridge design specifications. American Association of State Highway and Transportation Officials. Washington DC. 2012.

[11] M. J. N. Priestley, F. Seible, Y. Xiao and R. Verma. Steel jacket retrofitting of reinforced concrete bridge columns for enhanced shear strength Part 2: Test results and comparison with theory. ACI Material Journal. 91 (2), 537-551. 1994. https://doi.org/10.14359/4168

[12] A. Lynn, Seismic evaluation of existing reinforced concrete building columns. University of California at Berkeley; 1999.

[13] H. Sezen and J. P. Moehle, Seismic behavior of shearcritical reinforced concrete building columns. Seventh U.S. National Congress of Earthquake Engineering. Boston: Massachusetts: Earthquake Engineering Research Institute; 3847-385, 2002.

[14] P. Colajanni. A. Recupero and N. Spinella, Shear strength degradation due to flexural ductility demand in circular RC columns. Bulletin of Earthquake Engineering., 13. 1795-1807. 2015. https://doi.org/ 10.1007/s10518-014-9691-0

[15] C. Del Vecchio. M. Del Zoppo. M. Di Ludovico. G.M. Verderame and A. Prota, Comparison of available shear strength models for non-conforming reinforced concrete columns. Engineering Structures. 148, 312 327. 2017. https://doi.org/10.1016/j.engstruct.2017. 06.045 
[16] M. J. N. Priestley. R. Verma and Y. Xiao, Seismic shear strength of reinforced concrete columns. Journal of Structural Engineering. vol. 120(8). 2310-2329. 1994. https://doi.org/10.1061/(asce)0733-9445(1994) $120: 8(2310)$

[17] M. J. Kowalsky and M. J. N Priestley, Improved analytical model for shear strength of circular reinforced concrete columns in seismic regions. ACI Structural Journal, 97(3), 388-396. 2000. https://doi.org/10.14359/4633

[18] ATC 32. Applied Technology Council. Improved Seismic Design Criteria for California Bridges. Provisional Recommendations. 1996.

[19] H. Sezen and J.P. Moehle, Shear strength model for lightly reinforced concrete columns. Journal of Structural Engineering. 130(11), 1692-1703. 2004. https://doi.org/10.1061/(asce)07339445(2004)130:11( 1692)

[20] D. Biskinis and M. N. Fardis. Cyclic shear resistance for seismic design. based on monotonic shear models in fib Model Code 2010 and in the 2018 draft of Eurocode 2. Structural Concrete, 21, 1-22. 2019. https://doi.org/10.1002/suco.201900037

[21] ACI 318-19. Building code requirements for structural concrete. American Concrete Institute. Farmington Hill. MI; 2019.

[22] Eurocode-8. Design of structures for earthquake resistance. Part-1. General rules. seismic actions and rules for buildings. European Committee for Standardization. Brussels. 2004.

[23] TBDY'18. Türkiye Bina Deprem Yönetmeliği-Deprem etkisi altında binaların tasarımı için esaslar. Afet ve Acil Durum Yönetimi Başkanlığı. Ankara. 2018.

[24] TS500/2000. Betonarme yapıların tasarım ve yapım kuralları. Türk Standartları Enstitüsü. Ankara. 2000.

[25] H. Banchman. Seismic Conceptual Design of Buildings - Basic principles for engineers, architects, building owners and authorities. Swiss Agency for Development and Cooperation, 3th edition, Bern; 2003.

[26] M. Moretti, and T. P. Tassios, Behaviour of short columns subjected to cyclic shear displacements: experimental results. Engineering Structures, 29(8), 2018-29, 2007. https://doi.org/10.1016/j.engstruct. 2006.11.001

[27] T. Dirikgil, and O. Atas, Experimental investigation of the performance of diagonal reinforcement and CFRP strengthened RC short columns. Composite Structures, 223, 1-15, 2019. https://doi.org/10.1016/j.compstruct. 2019.110984

[28] T. Dirikgil, Experimental investigation of the contributions of CFRP and externally collar strengthening to the seismic performance of $\mathrm{RC}$ columns with different cross-sections. Structures, 24, 266-281, 2020. https://doi.org/10.1016/j.istruc. 2020.03.067

[29] FEMA 461. Interim testing protocols for determining the seismic performance characteristics of structural and nonstructural components. Federal Emergency Management Agency. Washington. D. C., 2007.

[30] FIB - Task Group 9.3. Bulletin 14: Externally bonded FRP reinforcement for RC structures. Lausanne. Switzerland: federation internationale du beton; 2001. https://doi.org/10.35789/fib.bull.0014.ch01

[31] ACI 440. Guide for the design and construction of externally bonded FRP systems for strengthening existing structures. Farmington Hills, MI: 2008. https://doi.org/10.14359/51700867

[32] CNR-DT 200. Guide for the design and construction of externally bonded FRP systems for strengthening existing structures. R1 ed. Rome: 2013.

[33] H-G. Park. E-J. Yu and K-K. Choi, Shear-strength degradation model for RC columns subjected to cyclic loading. Engineering Structures, 34, 187-197, 2012. https://doi.org/10.1016/j.engstruct.2011.08.041 


\section{Ekler}

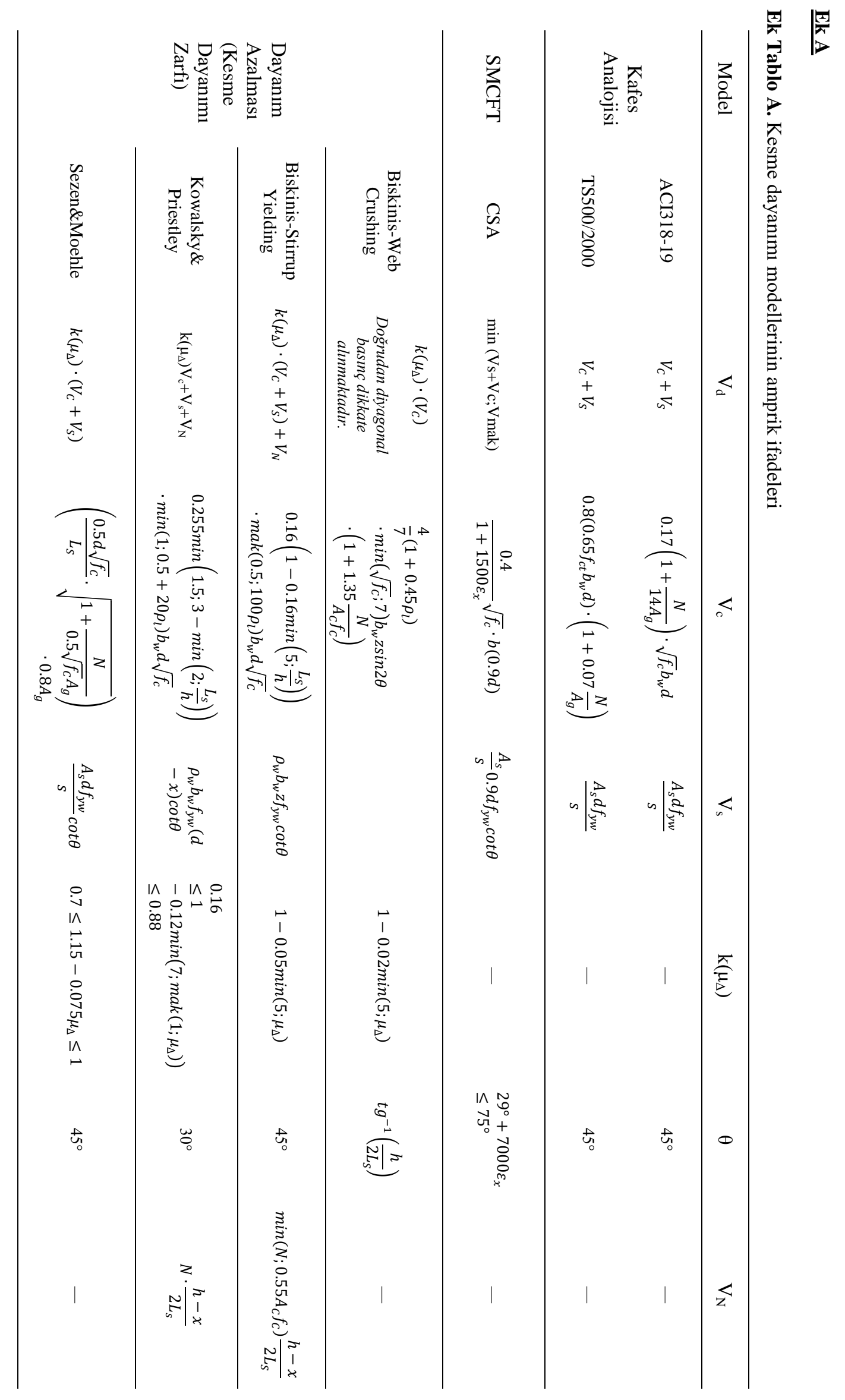




\section{Ek B}

\section{Kısaltmalar Listesi}

\begin{tabular}{|llll|}
\hline$A_{c}$ & Net kesit alanı & $s$ & Kesme donatısı aralı̆̆ı \\
$A_{g}$ & Brüt kesit alanı & $V_{c}$ & Betonun kesmeye katkısı \\
$A_{s}$ & Kesme donatısı alanı & $V_{N}$ & Eksenel yükün kesmeye katkısı \\
$b . b_{W}$ & Kesit genişliği & $V_{s}$ & Kesme donatısının kesmeye katkısı \\
$d$ & Faydalı derinlik & $X$ & Tarafsız eksen derinliği \\
$f_{c}$ & Betonun basınç dayanımı & $z$ & Yüklemeye dik yüzlerdeki iki boyuna donatı sırasının arasındaki \\
& & & mesafe \\
$f_{y}$ & Boyuna donatının akma dayanımı & $\alpha_{s}$ & Kesme açıklığı oranı \\
$f_{y W}$ & Kesme donatısının akma dayanımı & $\varepsilon_{X}$ & Etkili kesme derinliğinin ortasındaki şekil değiştirme \\
$h$ & Kesit derinliği & $\theta$ & Basınç çubuğu veya gerilme alanının düş̧eyle yaptığı açı \\
$k(\mu \Delta)$ & Düktilite talebi ile kesme dayanımı azalma & $\mu_{\Delta}$ & Düktilite talebi \\
& katsayısı & & \\
$L_{s}$ & Kesme açıklığı & $\rho_{l}$ & Boyuna donatı oranı \\
$N$ & Eksenel yük & $\rho_{W}$ & Kesme donatısı oranı \\
$n$ & Eksenel yük indeksi & & \\
\hline
\end{tabular}

